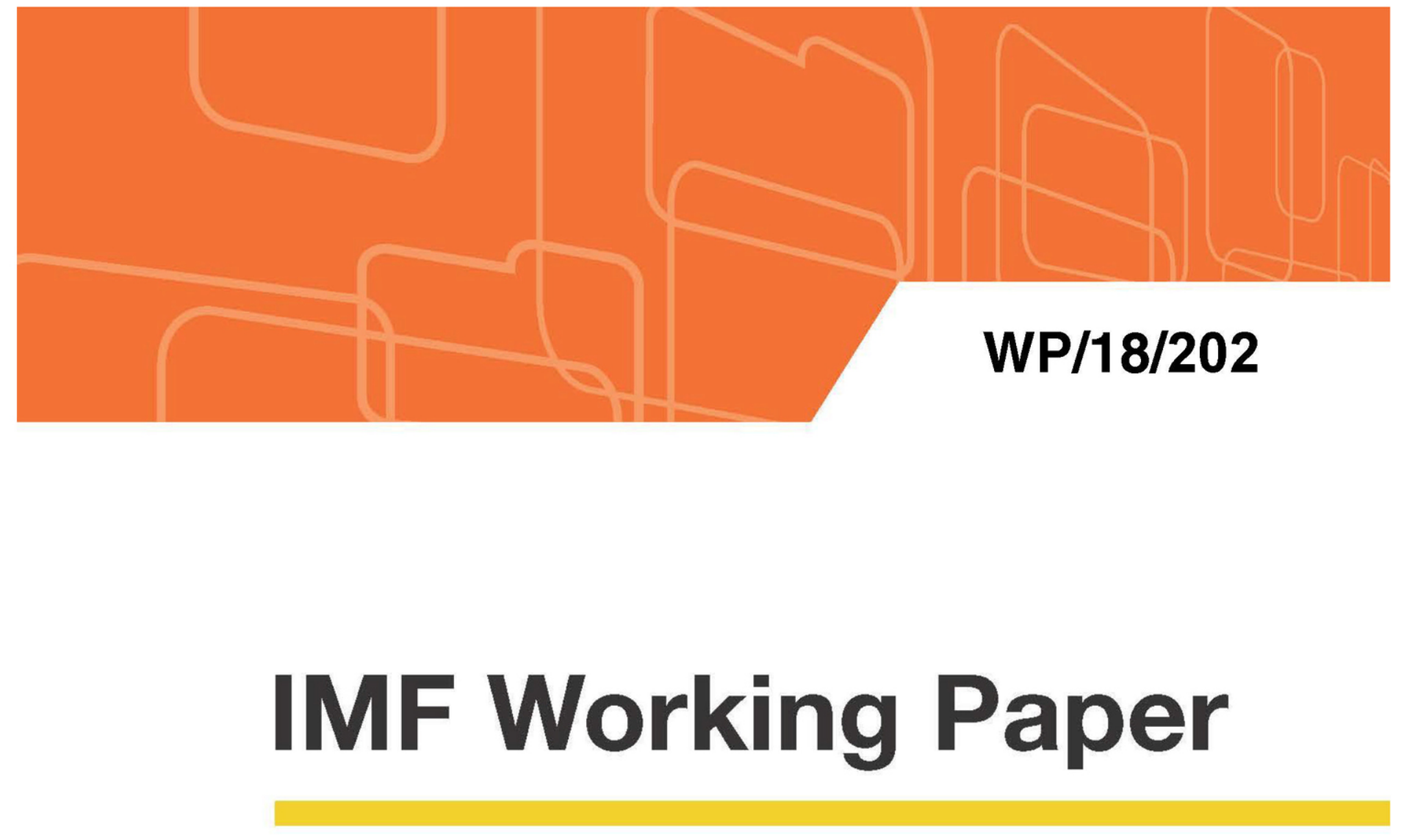

\title{
Cross-Border Credit Intermediation and Domestic Liquidity Provision in a Small Open Economy
}

by Thorvardur Tjoervi Olafsson

IMF Working Papers describe research in progress by the author(s) and are published to elicit comments and to encourage debate. The views expressed in IMF Working Papers are those of the author(s) and do not necessarily represent the views of the IMF, its Executive Board, or IMF management.

$$
\text { I N T E R N A T I O N A L M O N E T A R Y F U N D }
$$




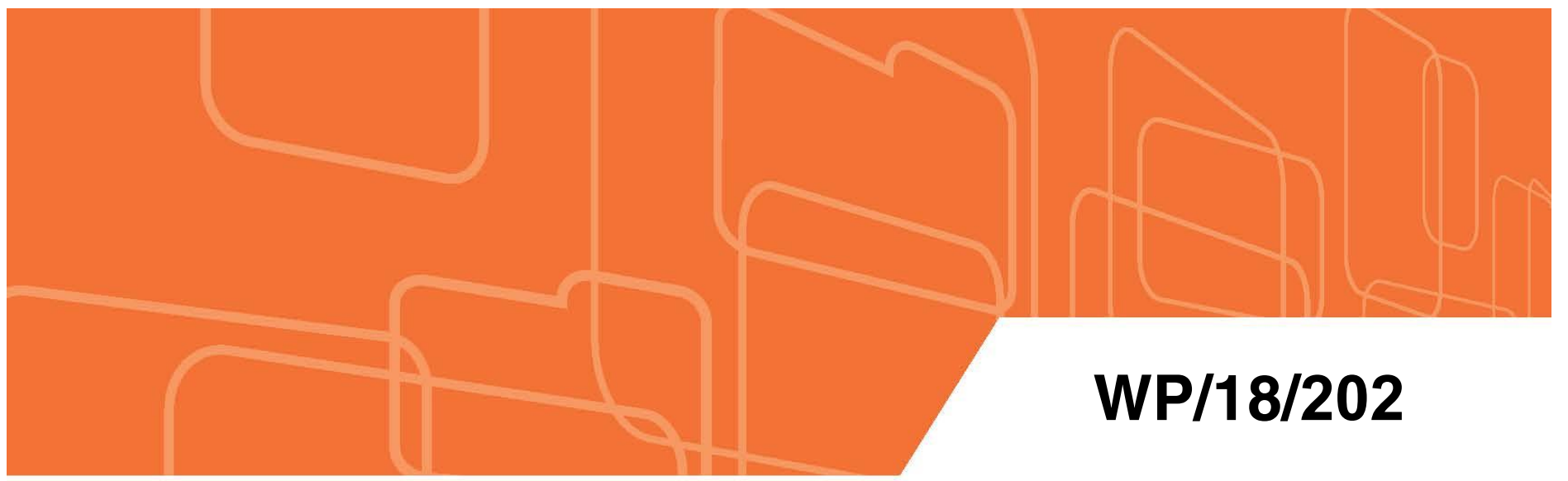

\section{IMF Working Paper}

\section{Cross-Border Credit Intermediation and Domestic Liquidity Provision in a Small Open Economy}

by Thorvardur Tjoervi Olafsson

IMF Working Papers describe research in progress by the author(s) and are published to elicit comments and to encourage debate. The views expressed in IMF Working Papers are those of the author(s) and do not necessarily represent the views of the IMF, its Executive Board, or IMF management.

$$
\text { I N T E R N A T | O N A L M O N E T A R Y F U N D }
$$




\title{
IMF Working Paper
}

Monetary and Capital Markets Department

\section{Cross-Border Credit Intermediation and Domestic Liquidity Provision in a Small Open Economy}

\section{Prepared by Thorvardur Tjoervi Olafsson ${ }^{1}$}

Authorized for distribution by Gaston Gelos

September 2018

\section{IMF Working Papers describe research in progress by the author(s) and are published to elicit comments and to encourage debate. The views expressed in IMF Working Papers are those of the author(s) and do not necessarily represent the views of the IMF, its Executive Board, or IMF management.}

\begin{abstract}
This paper develops a small open economy model where global and domestic liquidity is intermediated to the corporate sector through two financial processes. Investment banks intermediate cross-border credit through interlinked debt contracts to entrepreneurs and commercial banks intermediate domestic savings to liquidity-constrained final good producers. Both processes are needed to facilitate development of key production inputs. The model captures procyclical investment bank leverage dynamics, global liquidity spillovers, domestic money market pressures, and macrofinancial linkages through which shocks propagate across the two processes, affecting spreads and balance sheets, as well as the real economy through investment and working capital channels.

JEL Classification Numbers: E3, E22, E44, F34, F41, G1

Keywords: financial frictions, cross-border banking flows, macrofinancial linkages, financial intermediation, working capital, credit contracts

Author's E-Mail Address: tolafsson@imf.org
\end{abstract}

\footnotetext{
${ }^{1}$ I would like to thank Mr. Ásgeir Daníelsson, Central Bank of Iceland and Mr. Karl Walentin, Sveriges Riksbank for their helpful comments and suggestions, as well as the Norges Bank and my previous employer, the Central Bank of Iceland.
} 


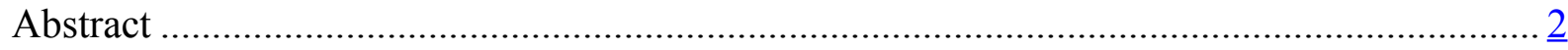

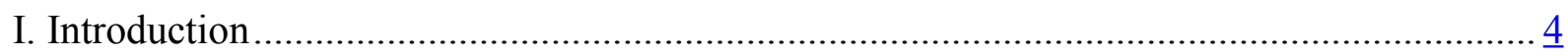

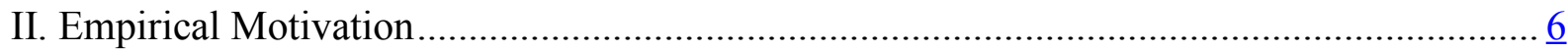

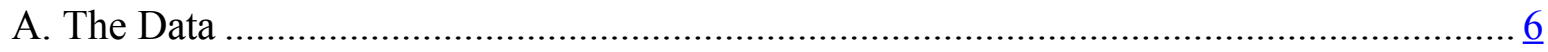

B. Cross-Border and Domestic Credit Developments in Small Open Economies.................. 7

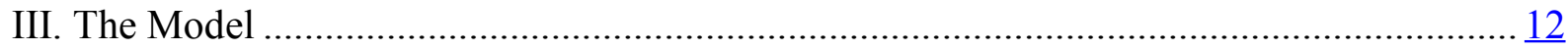

A. Overview of the Model................................................................................. 12

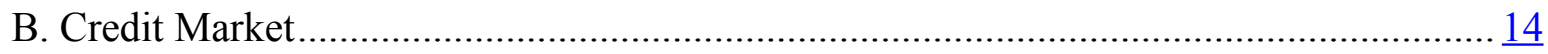

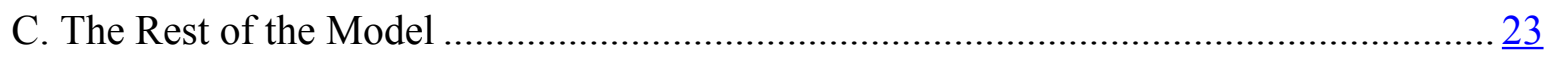

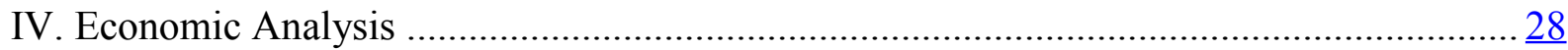

A. Risk Shock in the Entrepreneurial Sector............................................................... $\frac{32}{34}$

B. Risk Shock in Investment Banking .....................................................................

C. Domestic Money Market Shock ……………………….......................................

D. Global Liquidity Shock ……………………………..............................................

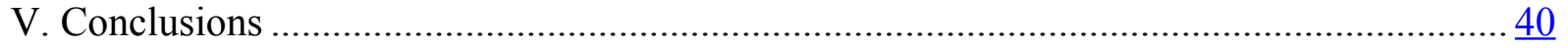

Tables

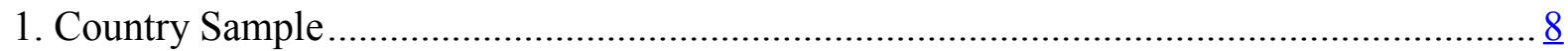

2. Summary Statistics for Cross-Border Credit............................................................. 9

3. Parameterization of the Model ...................................................................................

Figures

1. Cross-Border Banking Flows in Small Open Economies .............................................. 10

2. Cross-Border Credit and Domestic Bank Credit to the Domestic Non-Financial Private Sector in Advanced Small Open Economies ...............................................................11

3. Bird's Eye View of the Model ................................................................................ 14

4. Overview of the Model's Key Macrofinancial Linkage ………....................................... $\frac{30}{33}$

5. Impulse Responses to a Risk Shock in the Entrepreneurial Sector ..................................... $\frac{33}{35}$

6. Impulse Responses to a Risk Shock in Investment Banking ………………................... $\frac{35}{38}$

7. Impulse Responses to a Domestic Money Market Shock ………………………............ $\frac{38}{39}$

8. Impulse Responses to a Global Liquidity Shock ………………………………………... 39

Appendix

I. Solution to the Investment Banks' Maximization Problem ................................................. 42

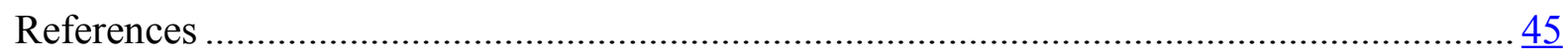




\section{INTRODUCTION}

This paper develops a small open economy model with a rich credit market set-up where global and domestic liquidity is intermediated to the corporate sector through two financial processes. In particular, global liquidity is intermediated by investment banks to entrepreneurs through interlinked credit contracts, which allow asymmetric information and bankruptcies to play a role, and give rise to interest rates and balance sheet relations through which crossborder financial intermediation and the real economy interact. On the other hand, commercial banks intermediate domestic liquidity to cash-in-advance constrained final good producers. Hence, production within the small open economy depends on both financial intermediation processes to enable funding and development of key production inputs.

The objective of this paper is to shed light on the interactions in small open economies between cross-border banking flows, domestic credit and liquidity extension, and aggregate production. In particular, with regard to the multifaceted macrofinancial linkages through which various financial shocks work their way across balance sheets and borders, the real economy, and the financial sector.

The paper is related to different strands of the literature. One strand is the renewed focus on global liquidity, cross-border banks, and international spillovers following the recent global financial crisis (International Monetary Fund (IMF), 2011a, Committee on the Global Financial System, 2011, Rey, 2013, McCauley et al., 2015). This literature emphasizes the importance of capital flows in general (Borio and Diyatat, 2011, Obstfeld, 2012a, b) and banking flows, in particular (IMF, 2011b, 2015a, McGuire and von Peter, 2012, Shin, 2012, Hahm et al., 2013, Cerutti et al., 2017, and Merrouche and Nier, 2017). It aims to expose the main determinants of net and gross capital flows (Forbes and Warnock, 2012, Broner et al., 2013, Ahmed and Zlate, 2014, Ghosh et al., 2014, and Tarashev et al., 2016) and analyze their interactions with domestic credit developments and the build-up of macroeconomic and financial stability risks (Mendoza and Terrones, 2008, Borio et al., 2011, Lane and McQuade, 2013, Caballero, 2014, Igan and Tan, 2015, and Ghosh et al., 2016). For instance, Shin (2012), Bruno and Shin (2015a), and Hofmann et al. (2016) emphasize the role of the United States (U.S.) investment banks' procyclical leverage (first identified by Adrian and Shin, 2009, 2010, 2011a) in determining the ease of funding in global markets and the capacity of currency movements to shift the supply between countries through the so-called risk-taking channel of currency appreciation. ${ }^{2}$

The model developed in this paper neither attempts to account for the determinants of global liquidity nor does it allow exchange rate fluctuations to play a role. Instead, the emphasis is on providing a dynamic stochastic general equilibrium (DSGE) framework that is able to capture important interlinkages between cross-border banking flows, domestic credit, and the real economy. This represents an uncommon endeavor as the modeling approach with regard to cross-border banks has mainly consisted of deriving partial equilibrium models (Bruno and Shin, 2015a and Hofmann et al., 2016). The paper also provides motivation for modeling interactions between cross-border and domestic credit developments by utilizing banking statistics from the Bank of International Settlements (BIS) for a sample of fifty countries.

\footnotetext{
${ }^{2}$ Shin (2013), Turner (2014), and Chui et al. (2016) analyze the so-called second phase of global liquidity where bond flows replaced banking flows. The model developed in this paper is silent on such developments.
} 
Another strand of literature that this paper is related to is the financial accelerator literature, especially its segment that makes use of Townsend's (1979) costly state verification framework, which was first introduced into a general equilibrium model in Bernanke et al. (1999). The literature traditionally emphasizes the role of financial frictions in credit demand due to balance sheet constrained non-financial borrowers (Bernanke and Gertler, 1989, Kiyotaki and Moore, 1997, Carlström and Fuerst, 1997, and Bernanke et al., 1999). The key ingredient in these models is the so-called external finance premium, which lenders charge non-financial borrowers due to asymmetric information and bankruptcy risk. The premium depends inversely on the strength of borrowers' balance sheets as lenders' potential losses are greater when borrowers' net worth and collateral values are lower. ${ }^{3}$

A shortcoming of traditional financial accelerator models is that they typically assume that firms effectively borrow directly from households and treat financial intermediaries simply as a veil, deeming them to play a passive role in business cycle dynamics. The recent global financial crisis, however, has provoked renewed interest into the importance of financial institutions in macroeconomic dynamics (Adrian and Shin, 2011b and Claessens and Kose, 2017), echoing early advocates for an important role for banks in macroeconomic models (Gurley and Shaw, 1955, Brunner and Meltzer, 1963, and Tobin and Brainard, 1963). In some ways, the financial accelerator approach extends naturally to financial institutions, which face constraints on their ability to obtain funds, however, there are important differences in the composition of their balance sheet which need to be taken into account, for instance, their greater reliance on leverage.

Hirakata et al. (2009, 2011, 2013, 2016), and Ueda (2012) expand the framework in Bernanke et al. (1999) by introducing credit constrained financial institutions, in addition to credit constrained entrepreneurs. Hence, their framework applies the costly state verification structure to two stages in credit intermediation and can account for a wider variety of macrofinancial linkages than the traditional models.

The model developed in this paper is a small open economy DSGE model where there are two financial intermediation processes with the former applying the Hirakata et al. $(2009,2016)$ framework of interlinked credit contracts to cross-border credit intermediation, while the latter process involves domestic liquidity provision to fund working capital costs. This is important as the significance of global spillovers and interrelations between financial systems has risen as global financial integration has increased. Due to the presence of working capital and domestic money markets, the final strands of literature that this paper is related to are on working capital in macroeconomic models (Christiano et al. 1995, Christiano, Motto, and Rostagno, 2010, Fernandez-Corugedo et al., 2011, Kim and Shin, 2012, 2013, Bruno et al., 2018 ) and the role of money market liquidity shocks and contagion across markets (Brunnermeier 2009, Brunnermeier et al. 2009, Ashcraft et al. 2011, IMF 2015b).

The model will be shown to be qualitatively capable of producing important macrofinancial behavior, such as procyclical leverage by investment banks, domestic money-market pressures, and global liquidity spillovers. The model represents a more complicated financial intermediation structure than in both Hirakata et al. $(2009,2016)$, which has no role for working capital, domestic money-market pressures, nor global liquidity shocks, and the above-mentioned working capital models, although they often include nominal and real frictions which are excluded here. Hence, the contribution of the paper is to provide a general

\footnotetext{
${ }^{3}$ Gertler, Gilchrist and Natalucci (2007), Devereux et al. (2006), Elekdag et al. (2004, 2006), Céspedes et al (2004), and Aghion et al. (2004) extended the traditional financial accelerator framework to the open economy.
} 
equilibrium modelling framework which is capable of providing qualitative insight into the importance of interconnectedness within the financial system and the multidimensional macrofinancial linkages that can transmit shocks both within the financial system, across borders, and throughout the real economy. This is assessed to be a more innovative exercise than adding a nominal side to models with simpler forms of financial frictions. The aim at this stage is therefore not to use the model for quantitative purposes, which would call for even more complicated structures, including introducing a nominal side.

The rest of the paper is structured as follows: Section 2 provides some empirical motivation for modeling the interactions between cross-border and domestic credit developments. The model is developed in Section 3 with special emphasis on the two financial intermediation processes. Section 4 describes the applied parameterization and presents the results of economic analysis of various shocks. Section 5 concludes.

\section{EMPIRICAL Motivation}

This paper emphasizes the interactions between the financial system and the real economy operating through cross-border banking flows, domestic credit and liquidity extension, and aggregate production. For motivational purposes, some empirical evidence is provided in this section on cross-border banking flows and domestic credit extension by utilizing BIS statistics on international and domestic banking activities.

\section{A. The Data}

The country sample includes 43 small open economies, in addition to seven large economies. To expose important differences in cross-border and domestic credit developments across different country groups, the sample is divided into groups with regard to income levels, geography, and financial system characteristics (i.e., with regard to whether each country's financial system is more bank- or market-based, as explained below). Table 1 gives an overview of the country sample and its division into different groups.

The source of data on cross-border credit and banking flows is the BIS locational banking statistics, which provide a comprehensive picture of cross-border exposures (i.e., loans, securities, and other claims) for a wide range of countries over a rather extensive time span. It is compiled following principles consistent with the balance of payments and is reported in U.S. dollars. Here, the exchange rate adjusted data is used to capture changes in the actual underlying positions of bank claims rather than effects of exchange rate movements. In particular, quarterly data covering the period from 1985Q1-2013Q4 is used.

Three different measures of cross-border credit are compiled. The first measure is domestic banks' gross cross-border liabilities, which captures the banks' overall reliance on funding from abroad. The approach follows Borio et al. (2011) and uses claims held by the rest of the world against banks in each country as a proxy for countries that do not report to the BIS (with claims on banks being given by the difference between claims on all sectors and claims on nonbanks in each country).

The second measure of cross-border credit is domestic banks' net cross-border liabilities, which represent the difference between banks' cross-border liabilities and their cross-border claims. Focus is limited to cases where this variable is positive to capture banks' use of crossborder credit to fund domestic credit. Hence, this measure can be referred to as indirect (or domestic bank-intermediated) cross-border credit. 
The third measure is direct cross-border credit to domestic nonbanks, which represents crossborder claims held by the rest of the world on nonbanks in each country (including on the government and domestic non-banking financial institutions). The aim is to compare the characteristics of such credit flows that by-pass domestic banks with the aforementioned bank-intermediated cross-border flows.

To capture domestic credit developments, the BIS statistics for domestic banks' credit to the non-financial private sector is used. As in Borio et al. (2011) and Tarashev et al. (2016) the published data is converted to constant 2013Q4 U.S. dollar exchange rate to ease the comparison with cross-border credit developments. As the BIS domestic credit statistics do not cover as many countries over such a long time span as the cross-border credit data, focus is for the most part limited to domestic credit developments in advanced small-open economies and they compared to the evolution of cross-border bank funding.

Crisis indicator variables from the Laven and Valencia (2013) database and GDP data from the IMF World Economic Outlook database are used to highlight developments in the run-up to and the aftermath of some financial distress and GDP contractionary episodes.

Finally, World Bank Development indicators are used, as in Demirguc-Kant et al. (2013), to construct a financial structure ratio for each country in the sample to split them into countries with market- and bank-based financial systems. The financial structure ratio is given by the mean ratio of private credit (i.e., deposit money bank credit to the private sector) to stock value traded over the sample period (as data availability allows). This categorization allows for further insight into the interactions between cross-border banking flows and domestic credit extension with regard to the relative importance of the banking system in domestic financial intermediation.

\section{B. Cross-Border and Domestic Credit Developments in Small Open Economies}

Table 2 summaries key properties of the three cross-border credit measures for the whole sample period and for two subsamples, which roughly divide the data into two equally long periods. The former subsample covers the period of global liberalization of financial markets, beginning in the mid-1980s, as well as the run-up to and aftermaths of financial crises in Scandinavia and East Asia in the 1990s. The latter subsample, however, covers the period leading up to the recent financial crisis and the subsequent years when the crisis unfolded and a weak recovery took place. Key statistics on domestic banks' gross and net cross-border funding, as well as direct cross-border credit to domestic nonbanks, are provided for the whole country sample and different country groups, i.e., advanced (also split into bank- and market-based) and emerging market small open economies.

As Table 2 shows, banks in small-advanced open economies have increased their crossborder funding more than their emerging market counterparts. This holds particularly for the degree to which banks make use of cross-border liabilities to fund their domestic assets (including credit) although there is evidence of increased tendencies to do the same among emerging market banks in the latter half of the period. Banks' cross-border funding seems to be more volatile (especially net liabilities) than cross-border credit extended directly to domestic nonbanks. Finally, banks' overall reliance on cross-border funding seems to have grown more rapidly and be more volatile in bank-based advanced countries than among small open economies that rely to a larger extent on financial markets. 
Table. 1. Country Sample

\begin{tabular}{|c|c|c|c|}
\hline \multicolumn{4}{|c|}{ Countries } \\
\hline $\begin{array}{l}\text { Argentina } \\
\text { Australia } \\
\text { Austria } \\
\text { Belgium } \\
\text { Brazil } \\
\text { Bulgaria } \\
\text { Canada } \\
\text { Chile } \\
\text { Croatia } \\
\text { Cyprus } \\
\text { Czech Republic } \\
\text { Denmark } \\
\text { Estonia }\end{array}$ & $\begin{array}{l}\text { Finland } \\
\text { France } \\
\text { Germany } \\
\text { Greece } \\
\text { Hong Kong } \\
\text { Hungary } \\
\text { Iceland } \\
\text { Indonesia } \\
\text { Ireland } \\
\text { Israel } \\
\text { Italy } \\
\text { Japan } \\
\text { Korea }\end{array}$ & $\begin{array}{l}\text { Latvia } \\
\text { Lithuania } \\
\text { Luxembourg } \\
\text { Malta } \\
\text { Malaysia } \\
\text { Mexico } \\
\text { Netherlands } \\
\text { New Zealand } \\
\text { Norway } \\
\text { Poland } \\
\text { Portugal } \\
\text { Romania } \\
\text { Russia }\end{array}$ & $\begin{array}{l}\text { Singapore } \\
\text { South Africa } \\
\text { Slovakia } \\
\text { Slovenia } \\
\text { Spain } \\
\text { Sweden } \\
\text { Switzerland } \\
\text { Thailand } \\
\text { Turkey } \\
\text { United Kingdom } \\
\text { United States }\end{array}$ \\
\hline \multicolumn{4}{|c|}{$\begin{array}{l}\text { Advanced economies } \\
\text { Australia, Austria, Belgium, Canada, Denmark, Finland, France, Germany, Greece, } \\
\text { Hong Kong, Iceland, Ireland, Israel, Italy, Japan, Korea, Luxembourg, Netherlands, } \\
\text { New Zealand, Norway, Portugal, Spain, Sweden, Switzerland, United Kingdom, United } \\
\text { States. }\end{array}$} \\
\hline \multicolumn{4}{|c|}{$\begin{array}{l}\text { Emerging market economies } \\
\text { Argentina, Brazil, Bulgaria, Chile, Croatia, Cyprus, Czech Republic, Estonia, Hungary, } \\
\text { Indonesia, Latvia, Lithuania, Malaysia, Malta, Mexico, Poland, Romania, Russia, } \\
\text { Singapore, South Africa, Slovakia, Slovenia, Thailand, Turkey. }\end{array}$} \\
\hline \multicolumn{4}{|c|}{$\begin{array}{l}\text { Argentina, Australia, Austria, Belgium, Brazil, Bulgaria, Canada, Chile, Croatia, Cyprus, } \\
\text { Czech Republic, Denmark, Estonia, Finland, Greece, Hong Kong, Hungary, Iceland, } \\
\text { Indonesia, Ireland, Israel, Korea, Latvia, Lithuania, Luxembourg, Malaysia, Malta, Mexico, } \\
\text { Netherlands, New Zealand, Norway, Poland, Portugal, Romania, Russia, Singapore, } \\
\text { Slovakia, Slovenia, South Africa, Sweden, Switzerland, Thailand, Turkey. }\end{array}$} \\
\hline \multicolumn{4}{|c|}{$\begin{array}{l}\text { Advanced small open economies with bank-based financial systems } \\
\text { Austria, Belgium, Finland, Greece, Iceland, Ireland, Israel, Luxembourg, New Zealand, } \\
\text { Norway, Portugal. }\end{array}$} \\
\hline \multicolumn{4}{|c|}{$\begin{array}{l}\text { Advanced small open economies with market-based financial systems } \\
\text { Australia, Canada, Denmark, Hong Kong, Korea, Netherlands, Sweden, Switzerland. }\end{array}$} \\
\hline $\begin{array}{l}\text { A few geographi } \\
\text { (i) Central and } \\
\text { Estonia, Hung: } \\
\text { (ii) South-East } \\
\text { Thailand; (iii) S } \\
\text { American coun }\end{array}$ & $\begin{array}{l}\text { ountry group } \\
\text { ern European } \\
\text { atvia, Lithuan } \\
\text { n countries: } \mathrm{H} \\
\text { linavian count } \\
\text { Argentina, } \mathrm{BI}\end{array}$ & $\begin{array}{l}\text { ountries: Bulgar } \\
\text {, Romania, Rus } \\
\text { Indonesia, Kor } \\
\text { hark, Finland, N } \\
\text { Mexico. }\end{array}$ & $\begin{array}{l}\text { Czech Republic, } \\
\text { kia, Slovenia; } \\
\text { sia, Singapore, } \\
\text { eden; (iv) Latin }\end{array}$ \\
\hline
\end{tabular}

Source: Author's assessment. 
Table 2. Summary Statistics for Cross-Border Credit

\begin{tabular}{|c|c|c|c|c|c|c|}
\hline & $\begin{array}{c}\text { Total } \\
(1985 Q 1\end{array}$ & $\begin{array}{l}\text { mple } \\
\text { 013Q4) }\end{array}$ & $\begin{array}{r}\text { Firs } \\
(1985 Q 1\end{array}$ & $\begin{array}{l}\text { alf } \\
99 Q 4)\end{array}$ & $\begin{array}{r}\text { Secol } \\
(2000 Q 1\end{array}$ & $\begin{array}{l}\text { Half } \\
13 Q 4)\end{array}$ \\
\hline & Mean & St.dev. & Mean & St.dev. & Mean & St.dev. \\
\hline & & & cross-bol & $r$ bank $f_{L}$ & & \\
\hline Country sample & 0.038 & 0.044 & 0.040 & 0.041 & 0.035 & 0.059 \\
\hline Advanced SOEs & 0.042 & 0.046 & 0.042 & 0.047 & 0.040 & 0.051 \\
\hline Emerging market SOEs & 0.025 & 0.059 & 0.019 & 0.029 & 0.037 & 0.074 \\
\hline SOES & 0.049 & 0.062 & 0.044 & 0.047 & 0.054 & 0.074 \\
\hline Advanced market-based & & & & & & \\
\hline SOES & 0.036 & 0.046 & 0.038 & 0.050 & 0.032 & 0.047 \\
\hline & & & oss-bc & bank fur & & \\
\hline Country sample & 0.034 & 0.068 & 0.031 & 0.069 & 0.042 & 0.088 \\
\hline Advanced SOEs & 0.044 & 0.092 & 0.050 & 0.093 & 0.042 & 0.093 \\
\hline Emerging market SOEs & 0.003 & 0.123 & 0.001 & 0.062 & 0.035 & 0158 \\
\hline Advanced bank-based & & & & & & \\
\hline SOEs & 0.050 & 0.118 & 0.047 & 0.146 & 0.056 & 0.115 \\
\hline SOEs & 0.050 & 0.136 & 0.045 & 0.141 & 0.057 & 0.128 \\
\hline & & Direct cr & order cre & to dome & onbanks & \\
\hline Country sample & 0.038 & 0.038 & 0.038 & 0.038 & 0.038 & 0.045 \\
\hline Advanced SOEs & 0.039 & 0.039 & 0.034 & 0.033 & 0.051 & 0.048 \\
\hline Emerging market SOEs & 0.032 & 0.047 & 0.033 & 0.050 & 0.021 & 0.059 \\
\hline Advanced bank-based & & & & & & \\
\hline SOEs & 0.045 & 0.049 & 0.042 & 0.036 & 0.056 & 0.060 \\
\hline Advanc & & & & & & \\
\hline SOEs & 0.037 & 0.040 & 0.032 & 0.041 & 0.047 & 0.046 \\
\hline
\end{tabular}

Source: Author's calculations.

Figure 1 provides a graphical representation of cross-border credit developments in different groups of small open economies over the sample period. The upper-panel shows the expansion of domestic banks' gross and net cross-border liabilities. The prolonged expansion and subsequent deleveraging by emerging market banks in the run-up to and aftermath of the East Asian financial crisis during the 1990s is evident, as well as the even more extreme evolution in advanced economies with regard to the recent global financial crisis. During the recent post-crisis era, banks' cross-border funding recovered swiftly in emerging markets and market-based advanced economies, but continued to contract for years in bank-based advanced economies.

The lower-panel of Figure 1 shows cross-border banking for specific geographical groups (1c) and selected individual countries (1d). There is a notable difference in the intensity and volatility of banks' cross-border liabilities developments between different geographical country groups. For instance, South-East Asian countries had just reached their pre-EastAsian-crisis peak in gross cross-border funding when the recent global crisis caused a swift, but short-lived, decline. Central and Eastern European countries, however, experienced an 
even more rapid increase in the run-up to the recent crisis and gross cross-border banking flows did not stage a lasting recovery during the rest of the sample period.

Figure 1. Cross-Border Banking Flows in Small Open Economies ${ }^{1}$

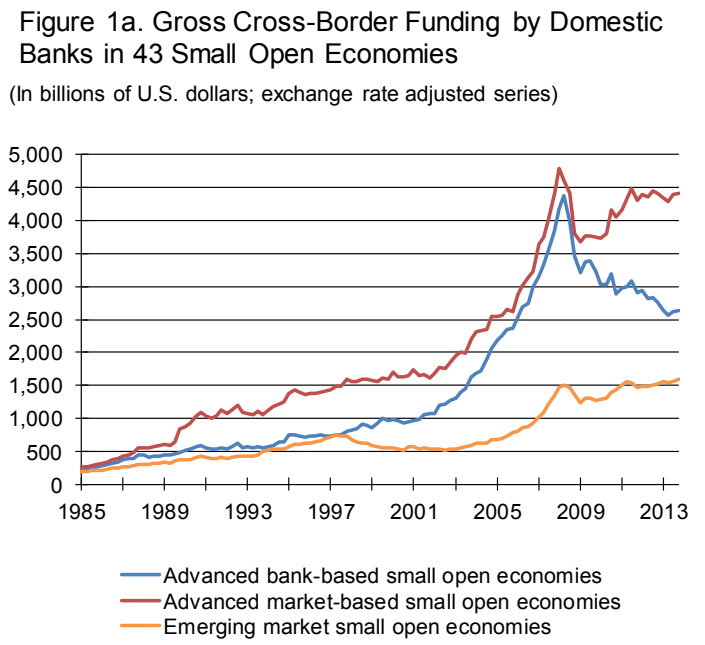

Figure 1c. Gross Cross-Border Funding By Domestic Banks in Selected Country Papers

(In billions of U.S. dollars; exchange rate adjusted series)

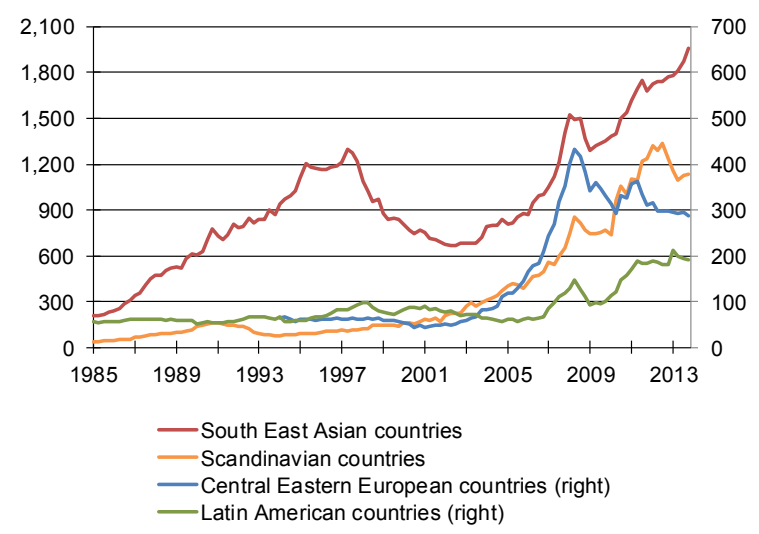

Figure 1b. Net Cross-Border Funding by Domestic Banks in a Sample of 43 Small Open Economies

(In billions of U.S. dollars (exchange rate adjusted series)

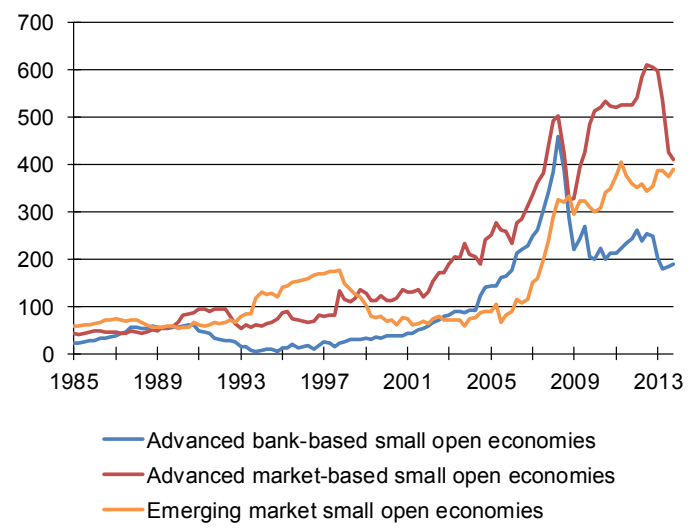

Figure 1d. Net Cross-Border Funding by Domestic Banks and Financial Crises in Selected Countries

(In billions of U.S. dollars; exchange rate adjusted series)

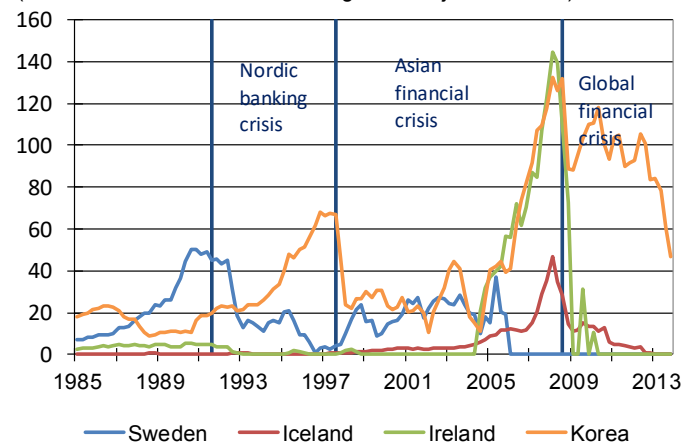

Sources: BIS locational banking statistics, author's calculations, and Laeven and Valencia (2013).

1/ Difference between cross-border liabilities of banks and their cross-border claims where the difference is positive. For nonBIS-reporting countries, banks' cross- border liabilities are proxied by claims held by BIS-reporting countries on those banks (where claims on banks are given by the difference between claims on all sectors and claims on non-banks) and in a similar fashion, the banks' cross-border claims are proxied by cross-border liabilities of BIS-reporting countries.

Figure 1d provides evidence of increased domestic banks' reliance on cross-border funding for domestic credit purposes in the run-up to various financial crises in selected small open economies. Korea is a noticeable example as net cross-border funding increased and subsequently declined during the bursting of the asset price bubble in Japan, the East Asian financial crisis, and the recent global crisis. The increase in net cross-border funding was also dramatic in the case of Ireland and Iceland, with Icelandic banks reaching a net cross-border 
funding position similar (in U.S. dollars) as banks in Sweden during the country's financial crisis in the early $1990 \mathrm{~s} .{ }^{4}$

Figure 2. Cross-Border Credit and Domestic Bank Credit to the Domestic Non-Financial Private Sector in Advanced Small Open Economies ${ }^{1}$

Figure 2a. Domestic Bank and Cross-Border Credit in Advanced Bank-Based Small Open Economies (In billions of U.S. dollars)

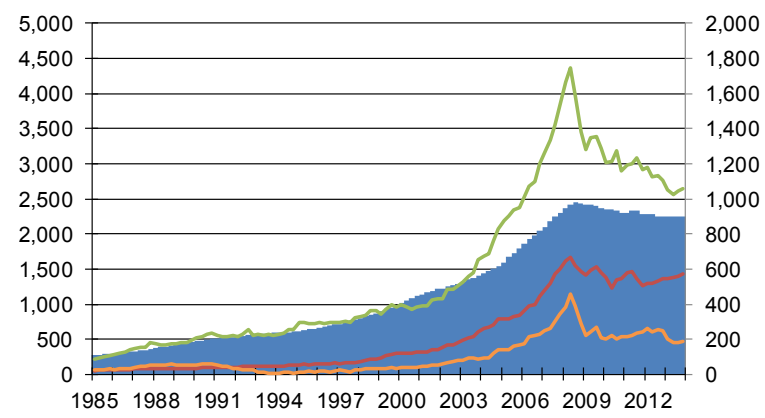

Domestic bank credit to the domestic private sector

-Direct cross-border credit to domestic non-banks

- Domestically-residented banks' gross cross-border funding

—Indirect (bank-intermediated) cross-border credit (right)

Figure 2c. Domestic Bank and Cross-Border Credit in Ireland

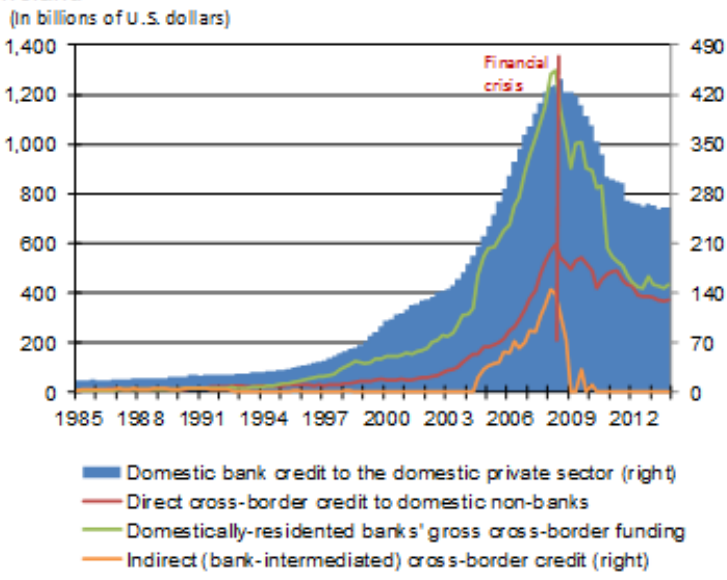

Figure 2b. Domestic Bank Credit and Cross-Border Credit in Advanced Market-Based SOEs (In billions of U.S. dollars)

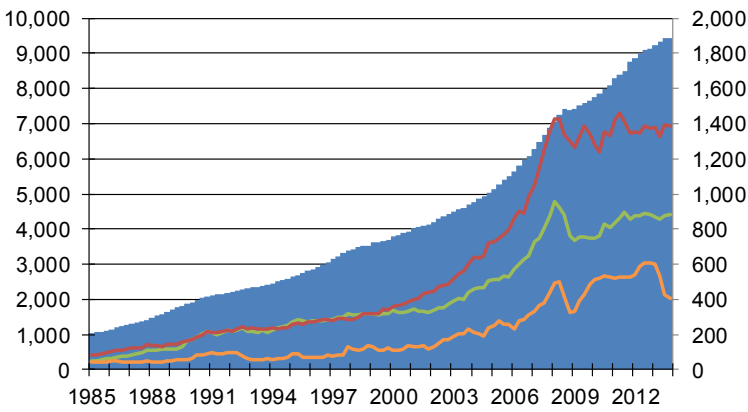

Domestic bank credit to the domestic private sector - Domestically-residented banks' gross cross-border funding - Direct cross-border credit to domestic non-banks

- Indirect (bank-intermediated) cross-border credit (right)

Figure 2d. Domestic Bank and Cross-Border Credit in Korea

(In billions of U.S. dollars)

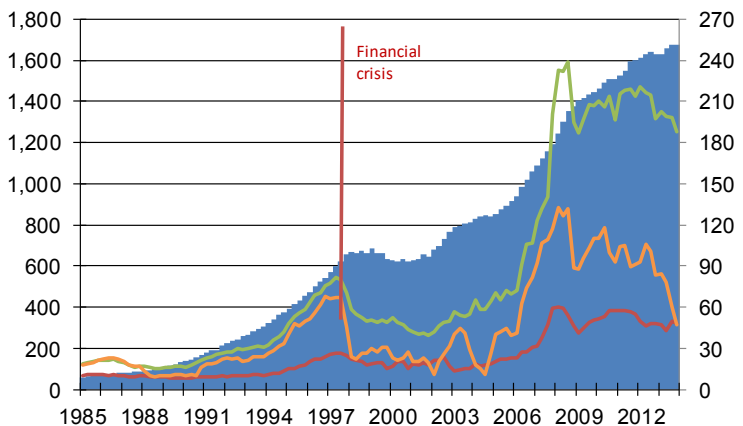

Domestic bank credit to the domestic private sector Direct cross-border credit to domestic non-banks (right) —Domestically-residented banks' gross cross-border funding (right) - Indirect (bank-intermediated) cross-border credit (right)

Sources: BIS Locational banking statistics; BIS credit data; IMF WEO database; Laeven, L. and F. Valencia (2013), Systemic Banking Crisis Database, IMF Economic Review, Vol. 61, pp. 225-270; author's own calculations.

1/ Domestic bank credit is in constant billion USD at 2013Q4. Cross- border credit is split into direct cross-border claims held by rest of the world on non-banks and indirect cross-border credit, i.e., domestic banks' net crossborder funding, which is given by the difference between their cross-border liabilities and cross-border claims (if the difference is positive). Also shows is the domestic banks' gross cross-border funding. Crisis dates are from Laven and Valencia (2013). Black lines indicate start of contraction in annual GDP.

Figure 2 shows the developments in the three measures of cross-border credit, as well as domestic bank credit to the nonfinancial private sector in advanced small open economies. The upper-panel provides evidence of contrasting developments in both cross-border and

\footnotetext{
4 A historical account of Icelandic banks' reliance on foreign funding and its financial and macroeconomic implications is provided in Einarsson et al. (2015, 2016).
} 
domestic bank credit between the two groups of advanced economies with regard to whether their financial intermediation is chiefly bank- or marked-based. The difference between crossborder banking flows in the two groups was discussed above, but Figure 2 reveals that this distinction also applies to domestic bank credit, which has contracted in bank-based economies but expanded in market-based economies. ${ }^{5}$ The figure also implies that there is something special about the part of cross-border credit, which is intermediated by domestic banks, as there is no clear difference between direct cross-border credit developments in the two country groups: in both cases foreign banks' credit extension to domestic nonbanks stagnates during the post-crisis era.

The lower-panel of Figure 2 portrays cross-border and domestic credit developments in two prominent examples, Ireland and Korea, with the former belonging to the bank-based group while the latter has a market-based financial system. Domestic banks' cross-border liabilities expanded rapidly in Ireland in the pre-crisis era, to the extent that a considerable net liability position had built-up as result of the banks' use of foreign funds to fuel the ongoing domestic credit boom. What followed was a severe systemic banking crisis with dramatic declines in cross-border banking flows (which were replaced by official flows) and a prolonged and severe contraction in domestic credit and economic activity. Again, the decline in direct crossborder credit to nonbanks is less severe compared to cross-border banking flows. Similar developments, although less severe in terms of magnitude and endurance of contraction in domestic credit took place in Korea in the East Asian crisis, but the country managed to escape from experiencing a banking crisis in the recent global crisis (although not necessarily currency crisis, Ólafsson and Pétursson, 2011), but nevertheless opted to introduce prudential measures to limit domestic banks' cross-border liabilities (Kim, 2014 and Bruno and Shin, 2014).

In short, the empirical evidence provided in this section suggest that there may be value in further analysis into the interactions between cross-border banking flows, on the one hand, and domestic credit and macroeconomic developments, on the other. In the next section, a small open economy DSGE model will be introduced that allows for some interactions of this kind, in particular by enabling shocks to be transmitted through domestic and cross-border credit intermediation, across balance sheets, and over to the real economy.

\section{THE MODEL}

In this section, a small open economy model is developed with the key element that funding and development of production inputs relies on both cross-border credit intermediation by investment banks and domestic liquidity provision by commercial banks.

\section{A. Overview of the Model}

Cross-border credit frictions and domestic liquidity constraints, with the former operating through an investment channel and the latter trough a working capital channel, play a pivotal role in the model and other types of market imperfections are excluded from the analysis. Hence, a credit market set-up with two financial intermediation processes is introduced into an otherwise standard version of the small open economy real business cycle model (Mendoza, 1991, and Schmitt-Grohé and Uribe, 2003).

\footnotetext{
${ }^{5}$ This difference is still present if countries experiencing a systemic banking crisis is excluded from both groups.
} 
As in the standard version, the model includes a single homogenous final good, single oneperiod internationally traded bond, and neither money nor other nominal variables. In the standard version, households accumulate capital and put capital to work in a completely straightforward manner. Furthermore, borrowers and lenders are implicitly assumed to be the same people and with no conflict of interest between them. In contrast, in this model, putting capital to work involves a special kind of creativity that only entrepreneurs possess and the transformation of new installed (raw) capital into effective capital services is risky. Importantly, entrepreneurs are assumed to have insufficient equity to finance their investments such that they borrow from domestic investment banks, who again need to borrow from global banks, as discussed below. This gives rise to interlinked debt contracts that are designed to mitigate the assumed asymmetry with regard to information on payoffs and the presence of bankruptcy risk. In addition, the model includes another financial intermediation process where commercial banks channel domestic savings to liquidity constrained final good producers. The combination of these two financial intermediation processes is at the heart of the nexus between the financial system and the real economy. ${ }^{6}$

There are 10 types of agents in the model: households, final good producers, entrepreneurs, capital producers, a government, a central bank, saving funds, investment banks, commercial banks, and global banks. The good market is assumed frictionless, i.e., input and output markets are fully competitive and nominal rigidities are absent. Final good producers use rented effective capital from entrepreneurs and labor from households, domestic financial institutions, and entrepreneurs to produce final goods using Cobb-Douglas technology. Importantly, final good producers are assumed to be liquidity constrained as they have to pay for their wage bill in advance. Commercial banks provide them with working capital loans, by intermediating domestic savings in the form of non-interest bearing household deposits and interest bearing certificates of deposits, which are purchased by saving funds in the money market. Commercial banks need to fulfil reserve requirements set by the central bank. Final goods are consumed domestically by households and the government, abroad, or used for investment. Capital producers possess the technology to transform final goods into new installed capital but their activities are subject to adjustment costs. Entrepreneurs use their own net worth and borrowed funds from investment banks to purchase new installed capital from capital good producers and provide effective capital services to the final good producers.

The transformation of new installed capital into effective capital is risky as the success of projects requires a combination of talent and good fortune. Hence, some entrepreneurs will go bankrupt, while others experience sufficient returns to repay their debt. This is taken into consideration in the design of the loan contract between investment banks and entrepreneurs. Domestic investment banks are both lenders and borrowers as they intermediate funds from the global banks to entrepreneurs but this intermediation is assumed risky, not only due to entrepreneurial credit risk, but also due to risk to the investment banks' capacity to manage their balance sheet given various (un-modeled) liquidity, market, and operational risk. This is taken into account in the design of the loan contract between global banks and the domestic investment banks. Figure 3 provides a bird's eye view of the model.

\footnotetext{
${ }^{6}$ As is common in models with financial frictions, this model does neither allow for substitution between bank credit and bonds, nor maturity transformation in financial intermediation.
} 
Figure 3. Bird's Eye View of the Model

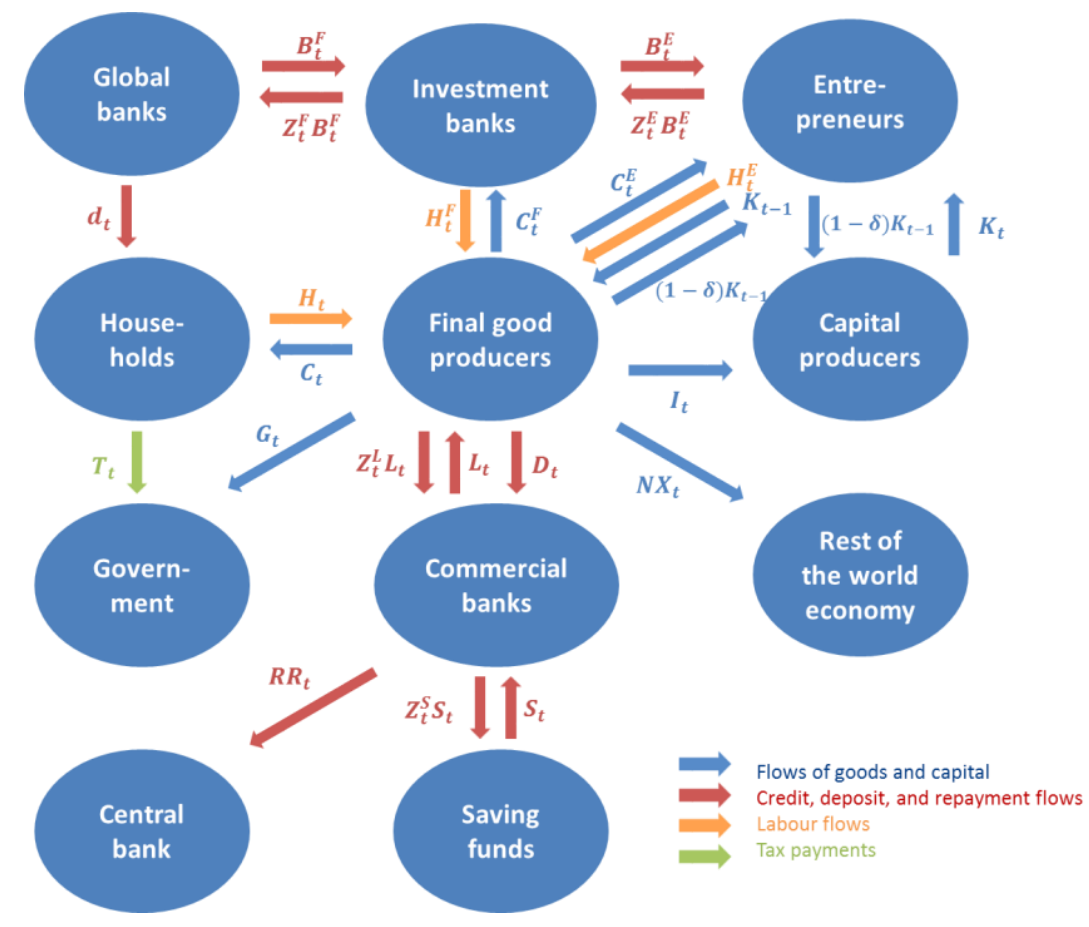

Source: Author's modeling.

\section{B. Credit Market}

This section describes the credit market of the model, which gives rise to various interest rate spreads and balance sheet relations, that play an important role in allowing developments in the credit market and the real economy to interact. This holds true in general for financial friction models, but the particular framework developed here provides an unusually high number of credit market participants and spreads compared to most other models. It can therefore include a number of shocks, originating both domestically and in global financial markets, and analyze their transmission across various macrofinancial linkages.

There are eight types of participants in the credit market: global banks, investment banks, entrepreneurs, commercial banks, saving funds, final good producers, the central bank, and households. The focus is on credit intermediation to the corporate sector (entrepreneurs and final good producers). Households are assumed to borrow to smooth consumption in a relatively frictionless manner and the dynamics of their borrowing plays a minor role within the model. They are for simplicity reasons assumed to borrow solely from global banks. The role of the central bank is also limited to liquidity regulation in the form of setting reserve requirements, which give rise to a spread between commercial banks' lending and funding rates.

This section is split into four parts: first, the base interest rate determination within the economy is established; second, the cross-border credit intermediation underpinning entrepreneurial investment activity is developed; third, the domestic liquidity provision to fund working capital is described, and finally, a graphical representation of the key macrofinancial linkages in the model is provided. 


\section{Domestic base interest rate}

The domestic base interest rate determination reflects the assumption that the small open economy faces a risk premium on top of the constant global risk free rate, $\bar{R}$. In particular, the model set-up follows Schmitt-Grohé and Uribe (2003) to introduce independence of the model's steady state from initial conditions by assuming that the small open economy faces a debt-elastic interest rate premium, which is subjected to an exogenous shock, $\mu_{t}^{g}$ (similar to the set-up in Garcia-Cicco et al., 2010):

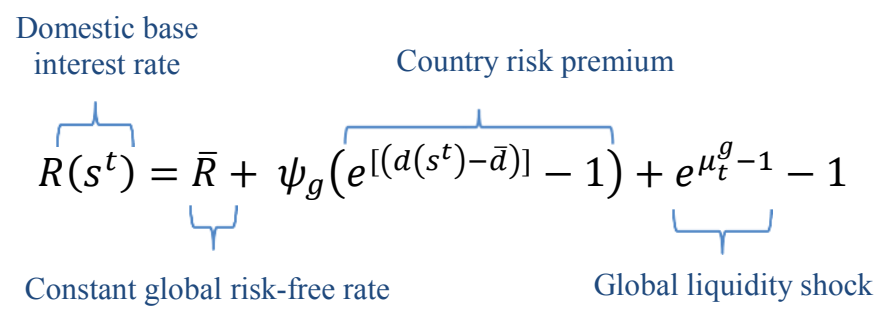

where $R$ represents the base interest rate within the domestic economy, $s^{t}$ is the state in period $t, \psi_{g}$ is a debt elastic interest rate parameter, $d$ is foreign debt, $\bar{d}$ is its steady state level. The domestic base interest rate therefore already includes one spread, which is affected by a global liquidity shock. As discussed in Garcia-Cicco et al. (2010), this shock can either be interpreted as a country specific risk premium shock, possibly reflecting domestic financial imperfections, or as a global liquidity shock, which is uncorrelated with the state of domestic fundamentals. Here the latter interpretation is applied as the model includes domestic financial frictions that give rise to country-specific interest rate spreads. The role of the shock is therefore to allow changes in global liquidity conditions to affect the base interest rate within the small open economy, which will again produce spillover effects on investment and overall production through the two financial intermediation processes (as described below).

\section{Intermediation process number 1: Cross-border credit intermediation by investment banks}

This part of the credit market describes the former financial intermediation process within the model. It relies on Hirakata et al. (2009, 2016), but as this model includes an additional financial intermediation process there are important departures from their model, for instance, including the presence of domestic liquidity constraints, a working capital channel, and commercial banks, which may face money market pressures and are subjected to regulatory restrictions. The model developed here therefore gives rise to macrofinancial linkages between aggregate production and a number of balance sheets, spreads, and shocks - both domestically and across borders. This will be discussed in more detail below.

This former financial intermediation process relates global banks, investment banks, and entrepreneurs through interlinked credit contracts. It is assumed that a continuum of risk neutral entrepreneurs invest in domestic projects transforming new installed capital into effective capital services. The entrepreneurs' net worth is insufficient to cover the cost of their investments and they therefore make one-period credit contracts with domestic investment banks. The investment banks have their own net worth but it is insufficient to finance their portfolio of entrepreneurial loans and they therefore make one-period credit contracts with global banks, which are assumed to accumulate deposits from households across the globe in a frictionless manner. 
The costly state verification framework applies to both contracts in this credit intermediation. Hence, both investment banks and entrepreneurs are assumed to be subjected to exogenous idiosyncratic productivity shocks and their assets returns assumed to be unobservable to their lenders except at a cost, interpretable as bankruptcy or monitoring cost. The entrepreneurs' idiosyncratic shock is a substitute for more complicated real life processes, such as the stochastic quality or success level of projects, and reflects the riskiness of corporate investments. The investment banks' idiosyncratic "productivity" shock is also a substitute for more complex actual processes, such as shocks to bankruptcy costs, technology of funding short-term assets and liabilities, and the overall quality and riskiness of their investments. The cost of funds for both investment banks and entrepreneurs are therefore set above the domestic base rate due to these information asymmetries and their associated bankruptcy costs. These interest rate spreads will then interact through the interlinked credit contracts.

Uncertainty in entrepreneurial return is modeled such that each entrepreneur is assumed to independently draw a random variable, $\omega^{E}$, assumed independent and identically distributed (i.i.d.) across entrepreneurs, which represents an idiosyncratic disturbance to each firm's return. The draw is assumed to be from a continuous and once differentiable cumulative distribution function (c.d.f.), $F^{E}\left(\omega^{E}\right)$, over a non-negative support and with a mean of unity. More precisely, the c.d.f. is assumed to be log-normal and its key property is captured by its standard deviation, which is denoted by $\sigma_{t}^{E}$. Entrepreneurs, which draw $\omega^{E} \geq \bar{\omega}^{E}$, experience sufficient returns to repay their debt, while those drawing $\omega^{E}<\bar{\omega}^{E}$ go bankrupt. The realization of $\omega^{E}$ is unknown at the time of credit extension and is afterwards only freely observable to the entrepreneur while the lender has to pay a monitoring cost to attain such information. The cross-sectional dispersion of $\omega^{E}$ is controlled by the risk parameter, $\sigma_{t}^{E}$, referred to as riskiness. As described in Section $\mathrm{C}$, innovations to this risk parameter are mean-preserving shocks and a negative risk shock makes the left tail of the distribution fatter, causing to more bankruptcies, and result in higher spreads and less borrowing. The uncertainty among investment banks is modeled in a parallel manner but with a different risk parameter, $\sigma_{t}^{F}$.

As in Hirakata et al. (2009, 2016), but different from Bernanke et al. (1999), investment banks are assumed to be monopolistic lenders of entrepreneurs that maximize profits and determine the borrowing rates of both contracts in this intermediation process, ensuring that the participation constraints of entrepreneurs and global banks are satisfied. More precisely, each investment bank, for instance a type $i$, makes loans agreements with a specific segment of entrepreneurs, say group $j_{i}$, which are attached to the bank. Each investment bank is assumed to be able to diversify the credit risk associated with each segment of entrepreneurs, ensuring a return on their loan portfolio equal to $R^{F}\left(s^{t}\right)$.

As in Hirakata et al. (2016), the investment banks and the entrepreneurs are both at the heart of the nexus between credit frictions and investment activity in the model, while entrepreneurs are alone in that role in the simpler set-up in Bernanke et al. (1999). The borrowing rates in the interlinked credit contracts change with fluctuations in riskiness and leverage of both investment banks and entrepreneurs, as well as due to various other shocks and spread changes in the model. In contrast to Hirakata et al. (2016), however, another financial intermediation takes place within the model and give rise to more macrofinancial linkages within the small open economy. 


\section{FE contracts}

The loan contracts between investment banks and entrepreneurs are standard loan contracts specifying both the amount of debt borrowed and the interest rate. Or, equally, contracts provide a menu of leverage and cut-off values of idiosyncratic disturbances to its real return on capital, $\bar{\omega}^{E}\left(s^{t}\right)$, where the cut-off values reflect when entrepreneurs can repay their debt. Hence, the cut-off value equalizes entrepreneurial profit and full loan repayment, reflecting that entrepreneurs with a lower $\omega^{E}$ will default:

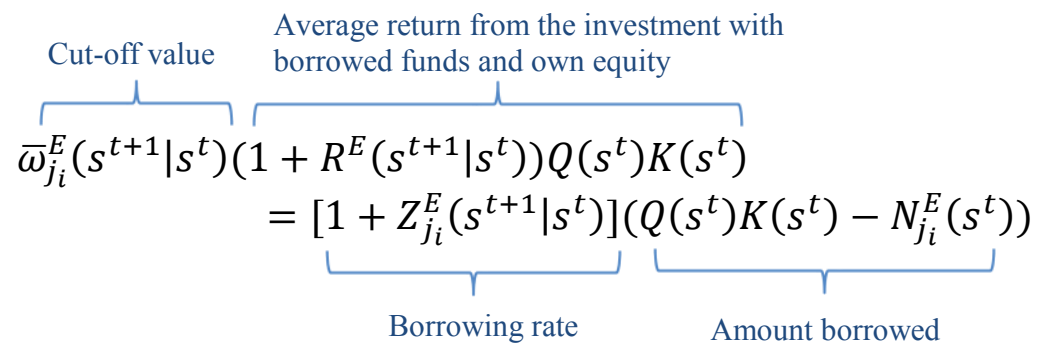

where $Z_{j_{i}}^{E}\left(s^{t+1} \mid s^{t}\right)$ is the lending rate. Hence, there is a direct relation between the cut-off value and the lending rate and it will prove to be easier to work with the cut-off value in solving the maximization problem of investment banks. Here, the focus is on cases where entrepreneurs' participation constraint is fulfilled such that they demand credit. This implies that their share of investment returns is equal to what they would have received from only investing their equity:

$$
\begin{aligned}
& \begin{array}{l}
\text { Share of entrepreneurial earnings } \\
\text { kept by the entrepreneur }
\end{array} \\
& \left\{\left(1-\Gamma_{t}^{E}\left(\bar{\omega}_{j_{i}}^{E}\left(s^{t+1} \mid s^{t}\right)\right)\right\}\left(1+R^{E}\left(s^{t+1} \mid s^{t}\right)\right) Q\left(s^{t}\right) K\left(s^{t}\right)\right. \\
& \text { with borrowed funds and own equity } \\
& \begin{array}{l}
\text { Average return from only } \\
\text { investing for own equity }
\end{array}
\end{aligned}
$$

In the expression above, $\left\{\left(1-\Gamma_{t}^{E}\left(\bar{\omega}_{j_{i}}^{E}\left(s^{t+1} \mid s^{t}\right)\right)\right\}\right.$, is the expected share of entrepreneurial earnings kept by the entrepreneurs, and, $\Gamma_{t}^{E}\left(\bar{\omega}_{j_{i}}^{E}\left(s^{t+1} \mid s^{t}\right)\right)$ the gross share of entrepreneurial earnings received by the investment banks, given by:

$$
\Gamma_{t}^{E}\left(\bar{\omega}_{j_{i}}^{E}\left(s^{t+1} \mid s^{t}\right)\right)=G_{t}^{E}\left(\bar{\omega}_{j_{i}}^{E}\left(s^{t+1} \mid s^{t}\right)\right)+\bar{\omega}_{j_{i}}^{E}\left(s^{t+1} \mid s^{t}\right) \int_{\bar{\omega}_{j_{i}}^{E}\left(s^{t+1} \mid s^{t}\right)}^{\infty} d F_{t}^{E}\left(\omega^{E}\right)
$$

where $G_{t}^{E}\left(\bar{\omega}_{j_{i}}^{E}\left(s^{t+1} \mid s^{t}\right)\right) \equiv \int_{0}^{\bar{\omega}_{j_{i}}^{E}\left(s^{t+1} \mid s^{t}\right)} \omega^{E} d F_{t}^{E}\left(\omega^{E}\right)$ represents the part of the c.d.f. where entrepreneurs default if they draw from that segment. The net share of entrepreneurial earnings going to the monopolistic investment banks is given by 


$$
\Phi_{j_{i, t}}^{E}\left(\bar{\omega}_{j_{i}}^{E}\left(s^{t+1} \mid s^{t}\right)\right) \equiv \Gamma_{t}^{E}\left(\bar{\omega}_{j_{i}}^{E}\left(s^{t+1} \mid s^{t}\right)\right)-\mu^{E} G_{t}^{E}\left(\bar{\omega}_{j_{i}}^{E}\left(s^{t+1} \mid s^{t}\right)\right)
$$

where $\mu^{E}$ represents the fixed share of entrepreneurial bankruptcy costs as a ratio of entrepreneurial total assets. Hence, entrepreneurial bankruptcy costs represent a deadweight loss to society due to the financial frictions and the costs are given by:

$$
\mu^{E} \bar{\omega}_{j_{i}}^{E}\left(s^{t+1}\right)\left(1+R^{E}\left(s^{t+1} \mid s^{t}\right)\right) Q\left(s^{t}\right) K\left(s^{t}\right)
$$

where $0<\mu^{E}<1$. This allows for expressing the investment banks' expected earnings (from each FE contract) as the net share of average aggregate return on capital:

$$
\Phi_{j_{i, t}}^{E}\left(\bar{\omega}_{j_{i}}^{E}\left(s^{t+1} \mid s^{t}\right)\right)\left(1+R^{E}\left(s^{t+1} \mid s^{t}\right)\right) Q\left(s^{t}\right) K\left(s^{t}\right)
$$

which also allows for defining the expected return on the loans to entrepreneurs, $[1+$ $\left.R^{F}\left(s^{t+1} \mid s^{t}\right)\right]$, as:

$$
\begin{aligned}
& \Phi_{j_{i, t}}^{E}\left(\bar{\omega}_{j_{i}}^{E}\left(s^{t+1} \mid s^{t}\right)\right)\left(1+R^{E}\left(s^{t+1} \mid s^{t}\right)\right) Q\left(s^{t}\right) K_{i}\left(s^{t}\right) \\
= & \left(1+R^{F}\left(s^{t+1} \mid s^{t}\right)\right)\left(Q\left(s^{t}\right) K\left(s^{t}\right)-N_{i}^{E}\left(s^{t}\right)\right), \forall s^{t+1} \mid s^{t}
\end{aligned}
$$

Where:

$$
\begin{aligned}
K_{i}\left(s^{t}\right) & \equiv \int_{j_{i}} K_{j_{i}}\left(s^{t}\right) d j_{i} \\
N_{i}^{E}\left(s^{t}\right) & \equiv \int_{j_{i}} N_{j_{i}}^{E}\left(s^{t}\right) d j_{i}
\end{aligned}
$$

\section{Global Commercial Banks (GCB) contracts}

The investment banks act as intermediaries of funds from global banks to the entrepreneurs. Hence, they borrow from global banks according to the GF contract, which has the same standard debt contract form resulting from the costly state verification framework as the FE contract. In a sense, the monopolistic investment banks split their share of the earnings resulting from the Commercial Bank Entrepreneurs (CBE) contract with global banks to obtain funding to finance their investment. Just as in the FE contract, there is a cut-off value, $\bar{\omega}^{F}\left(s^{t}\right)$, where the investment banks can repay their loans to global banks:

$$
\begin{aligned}
\bar{\omega}_{i}^{F}\left(s^{t+1} \mid s^{t}\right) & \left(1+R^{F}\left(s^{t+1} \mid s^{t}\right)\right)\left(Q\left(s^{t}\right) K_{i}\left(s^{t}\right)-N_{i}^{E}\left(s^{t}\right)\right) \\
& =\left[1+Z_{i}^{F}\left(s^{t+1} \mid s^{t}\right)\right]\left(Q\left(s^{t}\right) K_{i}\left(s^{t}\right)-N_{i}^{F}\left(s^{t}\right)-N_{j_{i}}^{E}\left(s^{t}\right)\right)
\end{aligned}
$$


where $Z_{i}^{F}\left(s^{t+1} \mid s^{t}\right)$ is the interest rate on the investment banks' loan and $\left[Q\left(s^{t}\right) K_{i}\left(s^{t}\right)-\right.$ $\left.N_{i}^{F}\left(s^{t}\right)-N_{j_{i}}^{E}\left(s^{t}\right)\right]$ the amount borrowed from global banks. As before, it is possible to interchange between the borrowing rates and the cut-off value. The participation constraint of global banks reflects that their earnings from the GF contract must equal their opportunity cost of lending:

$$
\begin{array}{r}
\left\{\Gamma_{t}^{F}\left(\bar{\omega}_{i}^{F}\left(s^{t+1} \mid s^{t}\right)\right)-\mu^{F} G_{t}^{F}\left(\bar{\omega}_{i}^{F}\left(s^{t+1} \mid s^{t}\right)\right)\right\}\left(1+R^{F}\left(s^{t+1} \mid s^{t}\right)\right)\left[Q\left(s^{t}\right) K_{i}\left(s^{t}\right)\right. \\
\left.-N_{i}^{E}\left(s^{t}\right)\right] \geq\left(1+R\left(s^{t}\right)\right)\left[Q\left(s^{t}\right) K_{i}\left(s^{t}\right)-N_{i}^{E}\left(s^{t}\right)-N_{i}^{F}\left(s^{t}\right)\right]
\end{array}
$$

\section{Optimal contracts}

The monopolistic investment banks solve a maximization problem subjected to the two participation constraints given by equations (3) and (12):

$$
\begin{aligned}
\max _{\bar{\omega}^{\mathrm{F}}, \bar{\omega}^{\mathrm{E}}, \mathrm{k}} \sum_{\mathrm{s}^{t+1}} \pi\left(\mathrm{s}^{\mathrm{t}+1} \mid \mathrm{s}^{\mathrm{t}}\right)[1 \\
\left.\quad-\Gamma^{\mathrm{F}}\left(\bar{\omega}^{\mathrm{F}}\left(\mathrm{s}^{\mathrm{t}+1} \mid \mathrm{s}^{\mathrm{t}}\right)\right)\right]\left[1+\mathrm{R}^{\mathrm{F}}\left(\mathrm{s}^{\mathrm{t}+1} \mid \mathrm{s}^{\mathrm{t}}\right)\right]\left[\mathrm{Q}\left(\mathrm{s}^{\mathrm{t}}\right) \mathrm{K}_{\mathrm{i}}\left(\mathrm{s}^{\mathrm{t}}\right)-\mathrm{N}_{\mathrm{i}}^{\mathrm{E}}\left(\mathrm{s}^{\mathrm{t}}\right)\right]
\end{aligned}
$$

where $\pi\left(s^{t+1} \mid s^{t}\right)$ is the probability weight for state $s^{t+1}$ given state $s^{t},\left[1-\Gamma^{F}\left(\bar{\omega}^{F}\left(s^{t+1} \mid s^{t}\right)\right)\right]$ represents the share of the investment banks' earnings kept by the institutions themselves, $\left[1+\mathrm{R}^{\mathrm{F}}\left(\mathrm{s}^{\mathrm{t}+1} \mid \mathrm{s}^{\mathrm{t}}\right)\right]$ is the average return on the FE contracts, and $\left[Q\left(s^{t}\right) K_{i}\left(s^{t}\right)-N_{i}^{E}\left(s^{t}\right)\right]$ the amount lent to entrepreneurs. It is beneficial when solving this maximization problem to use equation (8) to replace $\left[1+\mathrm{R}^{\mathrm{F}}\left(\mathrm{s}^{\mathrm{t}+1} \mid \mathrm{s}^{\mathrm{t}}\right)\right]\left[\mathrm{Q}\left(\mathrm{s}^{\mathrm{t}}\right) \mathrm{K}_{\mathrm{i}}\left(\mathrm{s}^{\mathrm{t}}\right)-\mathrm{N}_{\mathrm{i}}^{\mathrm{E}}\left(\mathrm{s}^{\mathrm{t}}\right)\right]$ with the equal expression $\Phi_{j_{i, t}}^{E}\left(\bar{\omega}_{j_{i}}^{E}\left(s^{t+1} \mid s^{t}\right)\right)\left(1+R^{E}\left(s^{t+1} \mid s^{t}\right)\right) Q\left(s^{t}\right) K_{i}\left(s^{t}\right)$. Appendix 1 provides details on the solution of the problem. ${ }^{7}$ The combined first-order-conditions are given by:

$$
\begin{gathered}
0=\sum \pi\left(s^{t+1} \mid s^{t}\right) \\
\left\{\left[1-\Gamma_{t}^{F}\left(\bar{\omega}_{i}^{F}\left(s^{t+1} \mid s^{t}\right)\right)\right] \Phi_{i, t}^{F}\left(s^{t+1} \mid s^{t}\right)\left[1+R^{E}\left(s^{t+1} \mid s^{t}\right)\right]\right\} \\
+\frac{\Gamma_{t}^{\prime F}\left(\bar{\omega}_{i}^{F}\left(s^{t+1} \mid s^{t}\right)\right)}{\Phi_{i, t}^{\prime F}\left(\bar{\omega}_{i}^{F}\left(s^{t+1} \mid s^{t}\right)\right)} \Phi_{i, t}^{F}\left(s^{t+1} \mid s^{t}\right) \Phi_{i, t}^{E}\left(s^{t+1} \mid s^{t}\right)\left[1+R^{E}\left(s^{t+1} \mid s^{t}\right)\right] \\
-\frac{\Gamma_{t}^{\prime F}\left(\bar{\omega}_{i}^{F}\left(s^{t+1} \mid s^{t}\right)\right)}{\Phi_{i, t}^{\prime F}\left(\bar{\omega}_{i}^{F}\left(s^{t+1} \mid s^{t}\right)\right)}\left[1+R\left(s^{t}\right)\right] \\
+\frac{\left[1-\Gamma_{t}^{F}\left(\bar{\omega}_{i}^{F}\left(s^{t+1} \mid s^{t}\right)\right)\right] \Phi_{i, t}^{\prime E}\left(s^{t+1} \mid s^{t}\right)}{\Gamma_{t}^{\prime E}\left(\bar{\omega}_{j_{i}}^{E}\left(s^{t+1} \mid s^{t}\right)\right)}\left[1-\Gamma_{t}^{E}\left(\bar{\omega}_{j_{i}}^{E}\left(s^{t+1} \mid s^{t}\right)\right)\right][1 \\
\left.+R^{E}\left(s^{t+1} \mid s^{t}\right)\right]
\end{gathered}
$$

\footnotetext{
${ }^{7}$ Analytical expressions for the variables appearing in equation (14) are available in Dynare and are listed in Hirakata et al. (2009).
} 


$$
\begin{gathered}
+\frac{\Gamma_{t}^{\prime F}\left(\bar{\omega}_{i}^{F}\left(s^{t+1} \mid s^{t}\right)\right) \Phi_{i, t}^{F}\left(s^{t+1} \mid s^{t}\right) \Phi_{i, t}^{\prime E}\left(s^{t+1} \mid s^{t}\right)}{\Phi_{i, t}^{\prime F}\left(\bar{\omega}_{i}^{F}\left(s^{t+1} \mid s^{t}\right)\right) \Gamma_{t}^{\prime E}\left(\bar{\omega}_{j_{i}}^{E}\left(s^{t+1} \mid s^{t}\right)\right)}\left[1-\Gamma_{t}^{E}\left(\bar{\omega}_{j_{i}}^{E}\left(s^{t+1} \mid s^{t}\right)\right)\right][1 \\
\left.+R^{E}\left(s^{t+1} \mid s^{t}\right)\right], \forall j_{i} .
\end{gathered}
$$

Equation (14) represents the efficiency condition for the interlinked credit contracts underpinning the cross-border and domestic credit intermediation in the model.

The two participation constraints can be rewritten to provide a pivotal relation between the excess return on domestic investment over the base rate needed for those investment activities to be funded (i.e., the external finance premium) given the set-up of the credit market, on the one hand, and the net worth in the investment banking and entrepreneurial sectors, respectively, on the other. Equation (3) can be rewritten as $\Phi_{i, t}^{F}\left(s^{t+1} \mid s^{t}\right) \Phi_{i, t}^{E}\left(s^{t+1} \mid s^{t}\right)[1+$ $\left.R^{E}\left(s^{t+1} \mid s^{t}\right)\right]=\left[1+R\left(s^{t}\right)\right]\left[1-\frac{N^{F}\left(s^{t}\right)}{Q\left(s^{t}\right) K\left(s^{t}\right)}-\frac{N^{E}\left(s^{t}\right)}{Q\left(s^{t}\right) K\left(s^{t}\right)}\right]$ and equation (12) as $[(1-$ $\left.\Gamma_{t}^{E}\left(\bar{\omega}^{E}\left(s^{t+1} \mid s^{t}\right)\right)\right] Q\left(s^{t}\right) K\left(s^{t}\right)=\frac{N^{F}\left(s^{t}\right)}{Q\left(s^{t}\right) K\left(s^{t}\right)}$ such that

$$
\frac{\left[1+R^{E}\left(s^{t+1} \mid s^{t}\right)\right]}{\left[1+R\left(s^{t}\right)\right]}=\left[\Phi_{t}^{F}\left(\bar{\omega}^{F}\right)\right]^{-1}\left[\Phi_{t}^{E}\left(\bar{\omega}^{E}\right)\right]^{-1}\left[1-\frac{N^{F}\left(s^{t}\right)}{Q\left(s^{t}\right) K\left(s^{t}\right)}-\frac{N^{E}\left(s^{t}\right)}{Q\left(s^{t}\right) K\left(s^{t}\right)}\right]
$$

Hence, the external finance premium is inversely related to the share of investment banks' earnings going to global banks (the first term on the right-hand-side), inversely related to the share of entrepreneurs' earnings that is received by the investment banks (the second-term), and positively dependent on the ratio of entrepreneurs' and investment banks' combined debt to aggregate capital (the third term). It seems straightforward that the cost of funds is lower when the lenders' share of the profits increases as reflected in the two first terms.

Furthermore, that bankruptcy costs increase in line with rising total debt, which should, given all else being equal, lead to higher exposed debt and hence higher credit spreads. However, it is interesting that equation (15) indicates that the distribution of net worth between the two borrowing sectors is an important determinant of the cost of funds. This reflects the important differences in the degree of leverage between firms (entrepreneurs) and financial institutions. Hirakata et al. (2016) analyze the quantitative importance of this distribution in greater detail.

This expression can be rewritten to relate cross-border banking flows to the domestic spread confronted by entrepreneurs and the share of their entrepreneurial profits going to lenders through the interlinked credit contracts:

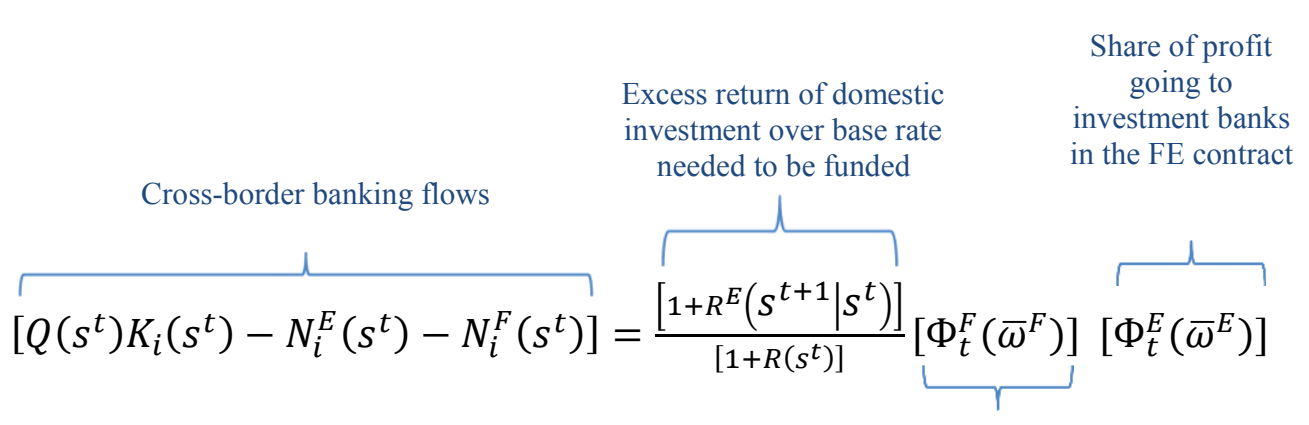


Entrepreneurs and investment banks build-up net worth through earnings from entrepreneurial projects split between them by the credit contract. Furthermore, both receive labor income from providing labor input to final good producers. In order to prevent entrepreneurs and investment banks from accumulating sufficient equity to fund their investments without borrowing I follow standard procedure and assume that a fraction of them dies each period and consumes their net worth. Hence, the law of motion for net worth is given by:

$$
\begin{aligned}
& N^{F}\left(s^{t}\right)=\gamma^{F} V^{F}\left(s^{t}\right)+W^{F}\left(s^{t}\right)+\Delta n^{F}\left(s^{t}\right) \\
& N^{E}\left(s^{t}\right)=\gamma^{E} V^{F}\left(s^{t}\right)+W^{E}\left(s^{t}\right)+\Delta n^{E}\left(s^{t}\right)
\end{aligned}
$$

where $\gamma^{F}$ and $\gamma^{E}$ are the survival rates, $\Delta n^{F}\left(s^{t}\right)$ and $\Delta n^{E}\left(s^{t}\right)$ are exogenous shocks defined below, and:

$$
\begin{gathered}
V^{F}\left(s^{t}\right)=\left[1-\Gamma_{t}^{F}\left(\bar{\omega}^{F}\left(s^{t+1} \mid s^{t}\right)\right)\right] \Phi^{E}\left(\bar{\omega}^{E}\left(s^{t+1} \mid s^{t}\right)\right)[1 \\
\left.+R^{E}\left(s^{t+1} \mid s^{t}\right)\right] Q\left(s^{t}\right) K\left(s^{t}\right) \\
V^{E}\left(s^{t}\right)=\left[1-\Gamma_{t}^{E}\left(\bar{\omega}^{E}\left(s^{t+1} \mid s^{t}\right)\right)\right]\left[1+R^{E}\left(s^{t+1} \mid s^{t}\right)\right] Q\left(s^{t}\right) K\left(s^{t}\right)
\end{gathered}
$$

\section{Intermediation process number 2: domestic liquidity provision by commercial banks}

This section describes the latter financial intermediation process in the model where commercial banks channel domestic savings to liquidity constrained final good producers. The set-up here does not rely on the costly state verification framework, hence there are neither any agency problems, a role for net worth, nor bankruptcies, as in the previously described cross-border intermediation process involving investment banks. However, the commercial banks involved in the process are assumed to operate within the scope of a central bank's liquidity regulation such that they, in contrast to the unregulated investment banks, are required to hold unremunerated reserves at the central bank. This latter intermediation process adds four participants, two interest rate spreads, and one shock, to the credit market in the model.

\section{Liquidity constrained final good producers}

Final good producers combine rented effective capital and labor inputs to produce the final good within the economy, as will be described in more detail in Section 3.3. Here the focus is on their need for liquidity from commercial banks. The producers are assumed to be cash-inadvance liquidity constrained as they need to pay for their labor inputs prior to receiving revenue from sales. Producers therefore attain working capital loans from commercial banks in the beginning of each period, pay for their wage bill, and need to save part of their sale revenue in the form of non-interest bearing deposits between periods to repay their loans. The constraint therefore implies the following for end-of-period deposits:

$$
D\left(s^{t}\right)=\left[1+R^{W}\left(s^{t}\right)\right] L\left(s^{t}\right)
$$


where $D\left(s^{t}\right)$ are end-of-period deposits, $R^{W}\left(s^{t}\right)$ the lending rate on the working capital loans, and $L\left(s^{t}\right)$ the amount borrowed. There are no profits (as discussed in Section 3.3) and the liquidity constraint therefore implies that producers borrow just exactly to fund their wage bill:

$$
L\left(s^{t}\right)=W\left(s^{t}\right) H\left(s^{t}\right)+W^{F}\left(s^{t}\right) H^{F}\left(s^{t}\right)+W^{E}\left(s^{t}\right) H^{E}\left(s^{t}\right)
$$

The composition of labor inputs is described in Section 3.3 where the final good producers' maximization problem is set up.

\section{Saving funds}

The source of funds in this intermediation process is, on the one hand, the non-interest bearing producers' deposits, but, on the other hand, it is assumed that there exist domestic saving funds who invest in interest-bearing certificates of deposits issued by commercial banks in domestic money markets. The use of funds in this process are, on the one hand, working capital loans to producers, and, on the other hand, bank reserves at the central bank (discussed below):

$$
S\left(s^{t}\right)=L\left(s^{t}\right)-D\left(s^{t}\right)+R R\left(s^{t}\right)
$$

where is $S\left(s^{t}\right)$ the amount invested by saving funds in commercial banks' certificates of deposits and $R R\left(s^{t}\right)$ represent unremunerated required reserves. The saving funds are for simplicity reasons assumed to be domestic money market participants that have the resources to invest in these certificates of deposits and the willingness to do so, given that they receive an interest rate above the domestic base interest rate level (TED spread). However, it is also assumed that domestic money market conditions can change. Hence, there is a money market spread over the domestic base interest rate, which is affected by a so-called domestic money market shock, which impacts the part of commercial banks' liabilities that are funded on that market:

$$
R^{S}\left(s^{t}\right)=R\left(s^{t}\right)+\psi_{D}\left(e^{\left[\left(\left(L\left(s^{t}\right)-\bar{L}\right)\right]\right.}-1\right)+e^{\mu_{t}^{S}-1}-1
$$

where $R^{S}\left(s^{t}\right)$ is the money market rate on certificates of deposits, $\psi_{D}$ is a balance sheet elastic interest rate parameter, $L\left(s^{t}\right)$ debt, $\bar{L}$ is its steady state level.

\section{Central bank}

The role of the central bank in the model is to serve as a liquidity regulator to commercial banks (which traditionally have access to central bank liquidity services and even lender-oflast-resort loans). The investment banks as well as the saving funds, however, are assumed to be unregulated. The liquidity regulation takes the form of requiring commercial banks to hold unremunerated reserves at the central bank. The reserve requirement is set as a (fixed) ratio of commercial banks' total liabilities:

$$
R R\left(s^{t}\right)=\varphi^{R R}\left[S\left(s^{t}\right)+D\left(s^{t}\right)\right]
$$

where $\varphi^{R R}$ is the reserve requirement ratio. This has the importance implication that a spread arises between the lending and funding rate of the commercial banks, as explained below. 


\section{Commercial banks}

The role of commercial banks in the model is to intermediate domestic savings to liquidity constrained final good producers, as well as to fulfil the reserve requirements set by the central bank. The model assumes complete competition in commercial banking and there is no role for net worth (i.e., bank capital). Hence, the representative commercial bank's total assets are given by the sum of working capital loans, $L\left(s^{t}\right)$, and unremunerated reserves, $R R\left(s^{t}\right)$, while their total liabilities are given by the sum of non-interest bearing producers' deposits, $D\left(s^{t}\right)$, and money market funding, $S\left(s^{t}\right)$. Hence, their balance sheet constraint implies that the interest rate on working capital loans is given by:

$$
\left[1+R^{W}\left(s^{t}\right)\right]=\left[\left[1+R^{S}\left(s^{t}\right)\right] S\left(s^{t}\right)+D\left(s^{t}\right)-R R\left(s^{t}\right)\right] / L\left(s^{t}\right)
$$

such that there is a spread between the lending and funding rate (i.e., money market rate) of the commercial banks.

This concludes the development of the credit market in the model. Given the focus on financial intermediation, the rest of the model is kept as simple as possible, as described in the next section.

\section{The Rest of the Model}

\section{Final good producers}

The representative final good producer faces perfectly competitive input and output markets and produces a tradable homogenous final good, $Y\left(s^{t}\right)$. Technology is assumed to exist that can be used to convert the homogeneous final good one-for-one into a private or public consumption good, $C\left(s^{t}\right)$ or $G\left(s^{t}\right)$, while the transformation into new installed capital, $K\left(s^{t}\right)$, is subjected to adjustment costs, as explained below. The key element of the model is that production within this small open economy relies on corporate credit being extended to fund production inputs. Credit constrained entrepreneurs supply effective capital services to the representative final producer for a rental price, $R^{E}\left(s^{t}\right)$. The final producer also hires labor from households, $H\left(s^{t}\right)$, the domestic financial institutions $H^{F}\left(s^{t}\right)$, and entrepreneurs $H^{E}\left(s^{t}\right)$, but importantly he/her is assumed to be liquidity constrained as the wage bill has to be paid in advance resulting in working capital loans from commercial banks, as described above.

Other details with regard to the final goods producer is that his technology is represented by a relatively standard Cobb-Douglas production function, adapted to the composition of labor inputs (which for simplicity reason exclude participants in the financial intermediation of domestic savings). It is assumed that at the end of each period, the un-depreciated capital is sold back to entrepreneurs at price $Q\left(s^{t}\right)$. Note that capital is assumed to depreciate during the production process within each period. This assumption regarding the reselling of the undepreciated capital is used to make the net worth of entrepreneurs well-defined at the end of each period, as they sell the un-depreciated capital further on to capital producers for the same price. The representative final producer's maximization problem is then given by:

$$
\begin{aligned}
& \max _{Y\left(s^{t}\right), K\left(s^{t-1}\right), H\left(s^{t}\right), H^{F}\left(s^{t}\right), H^{E}\left(s^{t}\right), L\left(s^{t}\right), D\left(s^{t}\right)} \\
& =Y\left(s^{t}\right)+Q\left(s^{t-1}\right) K\left(s^{t-1}\right)(1-\delta)
\end{aligned}
$$

Revenue from selling undepreciated capital back 


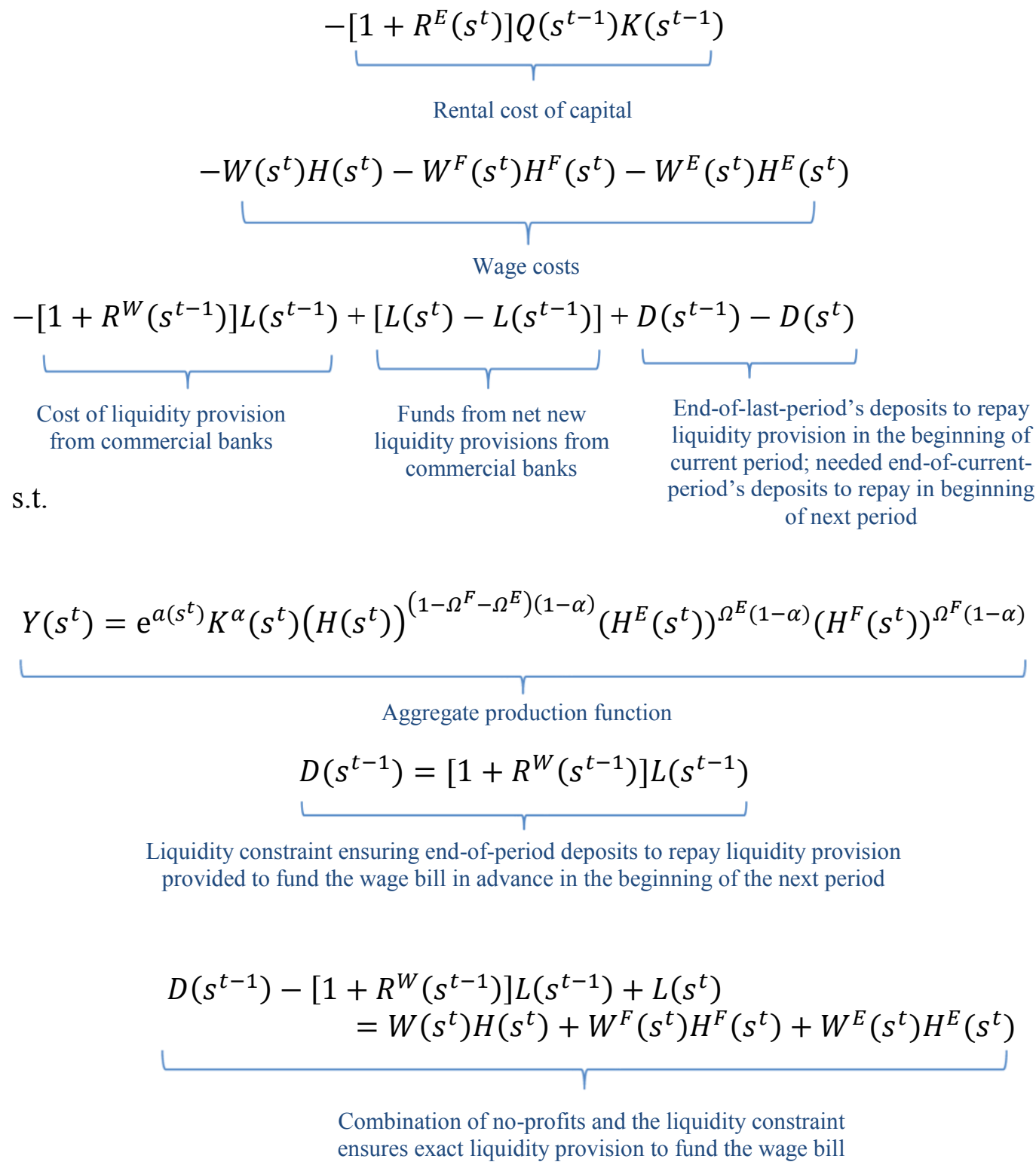

where $a\left(s^{t}\right), \delta, \alpha, \Omega^{F}$, and $\Omega^{E}$ are the economy-wide level of total factor productivity, the capital depreciation rate, the capital share, the share of domestic financial institutions' labor input, and the share of entrepreneurial labor input, respectively. The assumed stationary stochastic process for $a\left(s^{t}\right)$ is defined below. $L\left(s^{t}\right), D\left(s^{t}\right)$, and $R^{W}\left(s^{t}\right)$ are the working capital loans from commercial banks, the final good producer's non-interest-bearing deposits, and the lending rate, respectively.

The first-order conditions for the representative final good producer are straightforward, equalizing the marginal benefit of adding one extra unit of factor input to its marginal cost, taking the need for liquidity provision, and its associated deposits, to fund the wage bill into account:

$$
\alpha \frac{Y\left(s^{t}\right)}{K\left(s^{t-1}\right)}-\left[1+R^{E}\left(s^{t}\right)\right] Q\left(s^{t-1}\right)+Q\left(s^{t-1}\right)(1-\delta)=0
$$




$$
\begin{gathered}
(1-\alpha)\left(1-\Omega^{F}-\Omega^{E}\right) \frac{Y\left(s^{t}\right)}{H\left(s^{t}\right)}=W\left(s^{t}\right)\left[1+R^{W}\left(s^{t}\right)\right] \\
(1-\alpha) \Omega^{F} \frac{Y\left(s^{t}\right)}{H^{F}\left(s^{t}\right)}=W^{F}\left(s^{t}\right)\left[1+R^{W}\left(s^{t}\right)\right] \\
(1-\alpha) \Omega^{E} \frac{Y\left(s^{t}\right)}{H^{E}\left(s^{t}\right)}=W^{E}\left(s^{t}\right)\left[1+R^{W}\left(s^{t-1}\right)\right] \\
L\left(s^{t}\right)=W\left(s^{t}\right) H\left(s^{t}\right)+W^{F}\left(s^{t}\right) H^{F}\left(s^{t}\right)+W^{E}\left(s^{t}\right) H^{E}\left(s^{t}\right) \\
D\left(s^{t}\right)=\left[1+R^{W}\left(s^{t}\right)\right]\left[W\left(s^{t}\right) H\left(s^{t}\right)+W^{F}\left(s^{t}\right) H^{F}\left(s^{t}\right)+W^{E}\left(s^{t}\right) H^{E}\left(s^{t}\right)\right]
\end{gathered}
$$

\section{Capital producers}

The technology applicable to transform the final good of the small open economy into new installed capital is assumed to be in the hands of a single, perfectly competitive, representative capital producer. The capital producer buys $I\left(s^{t}\right)$ amount of final goods from the final good producer and combines it with the un-depreciated capital $(1-\delta) K\left(s^{t-1}\right)$ it bought from the entrepreneurs at price $Q\left(s^{t-1}\right)$. It then produces new installed capital, $K\left(s^{t}\right)$, from these inputs using technology subjected to adjustment costs, that are increasing in the rate of investment growth as defined below, and sells the new installed capital to entrepreneurs in a competitive market at price $Q\left(s^{t}\right)$. This paper follows Bernanke et al. (1999) in assuming that the price of new and used capital is the same (to the first order) and hence I can disregard the un-depreciated capital when setting up the maximization problem of the capital producer

$$
\begin{gathered}
\max _{I_{t+l}} \sum_{l=0}^{\infty} \pi\left(s^{t+l} \mid s^{t}\right) \Delta\left(s^{t+l}\right) \\
*\left[Q\left(s^{t}\right)\left(1-F_{I}\left(I\left(s^{t+l}\right), I\left(s^{t+l-1}\right)\right)\right) I\left(s^{t+l}\right)-I\left(s^{t+l}\right)\right]
\end{gathered}
$$

where the production technology is given by $F_{I}\left(I_{t+l}\left(s^{t+l}\right), I_{t+l-1}\left(s^{t+l-1}\right)\right) \equiv$ $\frac{\kappa}{2}\left(\frac{I_{t+l}\left(s^{t+l}\right)}{I_{t+l-1}\left(s^{t+l-1}\right)}-1\right)^{2}$ and $\Delta\left(s^{t}\right)$ is the capital producer's subjective discount factor. Note that the parameter, $\kappa$, determines the investment adjustment cost, and that those costs do not affects the steady state of the model where the relative price of capital goods in terms of the final good, or Tobin's $Q\left(s^{t}\right)$, is unity. Investment adjustment costs are typically included in small open economy models to avoid excessive investment fluctuations in response to changes in domestic productivity or foreign interest rates. Furthermore, they are useful when introducing financial frictions into real business cycle models to attain a decline in the price of capital and hence net worth in the case of a negative risk shock. The first-order-condition of the capital producer's maximization problem is given by: 


$$
\begin{gathered}
Q\left(s^{t}\right)\left[1-\frac{\kappa}{2}\left(\frac{I\left(s^{t}\right)}{I\left(s^{t-1}\right)}-1\right)^{2}\right]-Q\left(s^{t}\right)\left\lfloor\kappa\left(\frac{I\left(s^{t}\right)}{I\left(s^{t-1}\right)}\right)\left(\frac{I\left(s^{t}\right)}{I\left(s^{t-1}\right)}-1\right)\right\rfloor-1 \\
=E_{t}\left\{\beta \frac{C\left(s^{t}\right)}{C\left(s^{t+1}\right)} Q\left(s^{t+1}\right) \kappa\left(\frac{I\left(s^{t+1}\right)}{I\left(s^{t}\right)}\right)^{2}\left(\frac{I\left(s^{t+1}\right)}{I\left(s^{t}\right)}-1\right)\right\}
\end{gathered}
$$

where I have made use of the assumption that the capital producers are assumed to be owned by the households and hence have the same subjective discounting factor. The law of motion

for capital is traditional and reflects the presence of investment adjustment costs:

$$
K\left(s^{t}\right)=\left(1-F_{I}\left(I\left(s^{t}\right), I\left(s^{t-1}\right)\right)\right) I\left(s^{t}\right)+(1-\delta) K\left(s^{t-1}\right)
$$

\section{Households}

The small open economy is assumed to be populated by a continuum of infinitely lived households and the representative households maximizes its expected utility subject to its budget constraint:

$$
\max _{C\left(s^{t}\right), H\left(s^{t}\right), d\left(s^{t}\right)} \sum_{l=0}^{\infty} \beta^{t+l} E_{t}\left\{\log C\left(s^{t+l}\right)-\chi \frac{H\left(s^{t+l}\right)^{1+\frac{1}{\eta}}}{1+\frac{1}{\eta}}\right\}
$$

s.t.

$$
C\left(s^{t+l}\right)+\left(1+R\left(s^{t+l}\right)\right) d\left(s^{t+l}\right)+T\left(s^{t+l}\right)=d\left(s^{t+l+1}\right)+W\left(s^{t+l}\right) H\left(s^{t+l}\right)
$$

The budget constraint reflects that period $t$ expenditures (use of funds)-reflecting consumption, debt repayments, and lump-sum taxes - need to be funded by new loans, $d\left(s^{t+1}\right)$, and (after-tax) labor income earned from working for the final good producer. Note that profits of the capital producers are zero by assumption and do therefore not affect the households' budget constraint. Households borrow funds to smooth consumption at the domestic base interest rate, $R\left(s^{t}\right)$, that includes a country risk premium as defined above. The household's optimality conditions are standard:

$$
\begin{gathered}
\frac{1}{C\left(s^{t}\right)}=\beta E_{t}\left\{\frac{1}{C\left(s^{t+1}\right)} R\left(s^{t}\right)\right\} \\
W\left(s^{t}\right)=\chi H\left(s^{t}\right)^{\frac{1}{\eta}} C\left(s^{t}\right)
\end{gathered}
$$

\section{Government}

The government plays a passive role in the model and simply collects a lump-sum tax from households, $T\left(s^{t}\right)$, and maintains a balanced budget in each period:

$$
G\left(s^{t}\right)=T\left(s^{t}\right), \forall t
$$




\section{Net Exports and the Economy's Aggregate Resource Constraint}

The key distinction between closed and open economies is that they have different constraints as there is international trade and capital flows in an open economy. The credit market set-up also implies that the aggregate resource constraint has to reflect the deadweight loss due to bankruptcy costs in the entrepreneurial and domestic financial sector, in addition to accounting for the domestic financial institutions' and entrepreneurs' consumption. Hence, the final goods produced in the small open economy that are neither spent on domestic consumption by households, entrepreneurs, the domestic financial institutions, and the government, investment by the capital producers, nor monitoring costs, are the country's net exports:

$$
\begin{gathered}
N X\left(s^{t}\right)=Y\left(s^{t}\right)-C\left(s^{t}\right)-C^{E}\left(s^{t}\right)-C^{F}\left(s^{t}\right)-I\left(s^{t}\right)-G\left(s^{t}\right)-d E\left(s^{t}\right) \\
-d F\left(s^{t}\right)
\end{gathered}
$$

where entrepreneurial and the domestic financial institutions' consumption reflect that entrepreneurs and domestic financial institutions that fail to survive in period $t$ consume their net worth:

$$
\begin{gathered}
C^{E}\left(s^{t}\right)=\left(1-\gamma^{E}\right)\left(1-\Gamma^{E}\left(\bar{\omega}^{E}\left(s^{t+1}\right)\right)\right)\left[1+R^{E}\left(s^{t+1}\right)\right] Q\left(s^{t}\right) K\left(s^{t}\right) \\
C^{F}\left(s^{t}\right)=\left(1-\gamma^{F}\right)(1 \\
\left.\quad-\Gamma^{F}\left(\bar{\omega}^{F}\left(s^{t+1}\right)\right)\right) \Phi^{E}\left(\bar{\omega}^{E}\left(s^{t+1} \mid s^{t}\right)\right)\left[1+R^{E}\left(s^{t+1}\right)\right] Q\left(s^{t}\right) K\left(s^{t}\right)
\end{gathered}
$$

Monitoring costs were defined above.

\section{Exogenous shocks}

The small open economy model includes seven exogenous shocks: a global liquidity shock, commercial banks' funding shock, two risk shocks, two net worth (leverage) shocks, and a total factor productivity shock. I follow Garcia-Cicco et al. (2010) in assuming that the global liquidity shock follows a first-order autoregressive process:

$$
\log \mu_{t+1}^{g}=\rho_{\mu} g \log \mu_{t}^{g}+\varepsilon_{t+1}^{\mu^{g}} ; \quad \varepsilon_{t}^{\mu^{g}} \sim N\left(0, \sigma_{\mu^{g}}^{2}\right)
$$

The domestic funding shock affecting commercial banks is also assumed to follow a stationary first-order autoregressive process:

$$
\log \mu_{t+1}^{d}=\rho_{\mu^{d}} \log \mu_{t}^{d}+\varepsilon_{t+1}^{\mu^{d}} ; \quad \varepsilon_{t}^{\mu^{d}} \sim N\left(0, \sigma_{\mu^{d}}^{2}\right)
$$

The risk shocks are associated with idiosyncratic disturbances to the investment banks' and entrepreneurs' productivities, $\omega^{F}\left(s^{t}\right)$ and $\omega^{E}\left(s^{t}\right)$. As discussed above, $\omega^{F}\left(s^{t}\right)$ and $\omega^{E}\left(s^{t}\right)$, are assumed to be log-normally distributed with unit mean and time-varying standard deviation $-\sigma^{F}\left(s^{t}\right)$ and $\sigma^{E}\left(s^{t}\right)$ - referred to as riskiness. The innovations to these standard deviations are the risk shocks, $\sigma_{\sigma_{F}}^{2}$ and $\sigma_{\sigma_{E}}^{2}$ : 


$$
\begin{aligned}
& \log \left(\frac{\sigma^{F}\left(s^{t}\right)}{\bar{\sigma}^{F}}\right)=\rho_{\sigma_{F}} \log \left(\frac{\sigma^{F}\left(s^{t-1}\right)}{\bar{\sigma}^{F}}\right)+\varepsilon^{\sigma_{F}}\left(s^{t}\right) ; \varepsilon^{\sigma_{F}}\left(s^{t}\right) \sim \text { i. i. d. } N\left(0, \sigma_{\sigma_{F}}^{2}\right) \\
& \log \left(\frac{\sigma^{E}\left(s^{t}\right)}{\bar{\sigma}^{E}}\right)=\rho_{\sigma_{E}} \log \left(\frac{\sigma^{E}\left(s^{t-1}\right)}{\bar{\sigma}^{E}}\right)+\varepsilon^{\sigma_{E}}\left(s^{t}\right) ; \varepsilon^{\sigma_{E}}\left(s^{t}\right) \sim \text { i. i. d. } N\left(0, \sigma_{\sigma_{E}}^{2}\right)
\end{aligned}
$$

where $\bar{\sigma}^{F}$ and $\bar{\sigma}^{E}$ are the steady state values of the standard deviations. The economy-wide level of total factor productivity is assumed to follow a stationary first-order autoregressive process:

$$
a\left(s^{t}\right)=\rho_{A} a\left(s^{t-1}\right)+\varepsilon^{a}\left(s^{t}\right) ; \quad \varepsilon^{a}\left(s^{t}\right) \sim \text { i. i. d. } \quad N\left(0, \sigma_{a}^{2}\right)
$$

The net worth shocks in the entrepreneurial sector and in investment banking are also assumed to follow a first-order autoregressive process:

$$
\begin{aligned}
& \Delta n^{E}\left(s^{t}\right)=\rho_{n_{E}} n^{E}\left(s^{t-1}\right)+\varepsilon^{n^{E}}\left(s^{t}\right) ; \quad \varepsilon^{n^{E}}\left(s^{t}\right) \sim \text { i. i.d. } N\left(0, \sigma_{n E}^{2}\right) \\
& \Delta n^{F}\left(s^{t}\right)=\rho_{n_{F}} n^{F}\left(s^{t-1}\right)+\varepsilon^{n^{F}}\left(s^{t}\right) ; \quad \varepsilon^{n^{F}}\left(s^{t}\right) \sim \text { i.i.d. } \quad N\left(0, \sigma_{n E}^{2}\right)
\end{aligned}
$$

\section{Equilibrium}

An equilibrium consists of a set of prices: $\left\{R\left(s^{t}\right), R^{E}\left(s^{t}\right), R^{F}\left(s^{t}\right), R^{S}\left(s^{t}\right), R^{W}\left(s^{t}\right)\right.$, $\left.W\left(s^{t}\right), W^{E}\left(s^{t}\right), W^{F}\left(s^{t}\right), Q\left(s^{t}\right), R^{E}\left(s^{t+1} \mid s^{t}\right), R^{F}\left(s^{t+1} \mid s^{t}\right), Z^{E}\left(s^{t+1} \mid s^{t}\right), Z^{F}\left(s^{t+1} \mid s^{t}\right)\right\}_{t=0}^{\infty}$ and the allocations $\left\{\left\{\omega_{j_{i}}^{E}\left(s^{t+1} \mid s^{t}\right)\right\}_{j_{i}=1}^{\infty}\right\}_{t=0}^{\infty},\left\{\left\{\omega_{i}^{F}\left(s^{t+1} \mid s^{t}\right)\right\}_{i=1}^{\infty}\right\}_{t=0}^{\infty},\left\{\left\{N_{j_{i}}^{E}\left(s^{t}\right)\right\}_{j_{i}=1}^{\infty}\right\}_{t=0}^{\infty}$, $\left\{\left\{N_{i}^{F}\left(s^{t}\right)\right\}_{i=1}^{\infty}\right\}_{t=0}^{\infty},\left\{L\left(s^{t}\right), D\left(s^{t}\right), S\left(s^{t}\right), R R\left(s^{t}\right), Y\left(s^{t}\right), C\left(s^{t}\right), C^{E}\left(s^{t}\right), C^{F}\left(s^{t}\right), I\left(s^{t}\right), N X\left(s^{t}\right)\right.$, $\left.d\left(s^{t}\right), K\left(s^{t}\right), H\left(s^{t}\right), H^{E}\left(s^{t}\right), H^{F}\left(s^{t}\right)\right\}_{t=0}^{\infty}$ for a given fiscal policy $\left\{G\left(s^{t}\right), T\left(s^{t}\right)\right\}_{t=0}^{\infty}$, realization of exogenous variables

$\left\{\varepsilon_{t}^{\mu^{g}}\left(s^{t}\right), \varepsilon_{t}^{\mu^{d}}\left(s^{t}\right), \varepsilon^{a}\left(s^{t}\right), \varepsilon^{\sigma_{E}}\left(s^{t}\right), \varepsilon^{\sigma_{F}}\left(s^{t}\right), \varepsilon^{N_{E}}\left(s^{t}\right), \varepsilon^{N_{F}}\left(s^{t}\right)\right\}_{t=0}^{\infty}$, and initial conditions $N_{-1}^{E}, N_{-1}^{F}, K_{-1}$, such that for all $t, i, j_{i}$ :

i. the household maximizes its utility given the prices;

ii. the investment banks maximize their profits given the prices;

iii. the entrepreneurs maximize their profits given the prices;

iv. the commercial banks maximize their profits given the prices;

$\mathrm{v}$. the final goods producers maximize their profits given the prices;

vi. capital goods producers maximize their profits given the prices;

vii. the saving funds buy issued certificates of deposits given the prices;

viii. the central bank enforces its reserve requirements;

ix. the government budget constraint holds; and

x. markets clear.

\section{ECONOMic ANALYSIS}

Solving for the steady state represents a substantial challenge in this model. Christiano et al. $(2003,2010,2012)$ provide a method to solve a model with the traditional financial 
accelerator credit market set-up, but this is far more complicated in a framework combing interlinked credit contracts and domestic liquidity provision. Here the Dynare software is used to compute the steady state and linearize the model around the steady state. The computations are based on calibrating the model using traditional parameter values from the literature, as well to attain sensible interest rate spreads and shocks to those spreads.

The calibration follows Hirakata et al. $(2009,2016)$ and Bernanke et al. (1999) for many of the parameter values (Table 3). These include parameter values related to the real economy, such as the discount factor, capital depreciation rate, capital share, risk free interest rate, elasticity of labor, utility weight on leisure, investment adjustment costs, and most of the autoregressive parameters associated with the shocks. The calibration also follows Hirakata et al. $(2009,2016)$ to calibrate six parameters associated with the two credit contracts in the former financial intermediation process, i.e., the standard deviation of the idiosyncratic disturbances to investment banks' and entrepreneurs' productivity in steady state, the monitoring costs, and the two survival rates. The steady state value for household debt, $\bar{d}$, is set such that the household debt as a ratio to GDP is in line with the average for small open economies included in Cecchetti et al. (2011). The debt elastic interest rate parameter is taken from Schmitt-Grohé and Uribe (2003). The standard deviation of shocks to the global liquidity shock is based on Garcia-Cicco et al. (2010).

Parameters for the domestic money market are chosen to attain roughly the average historical quarterly interest rate spread between 3-month interbank rates and 3-month treasury bills (Ted spread), which is roughly 60 basis points (bps.) over the period 1986-2016. The money market shock is calibrated to produce a roughly $200-250 \mathrm{bps}$. increase in the TED spread, as has been the case in a few episodes over this period. The Central Bank's reserve requirement ratio is set to produce a roughly 300 bps. spread between commercial banks' lending and funding rate. This implies a high value for the ratio, but its main role within the model is to produce a lending to funding spread of reasonable value.

Before analyzing the equilibrium responses of the model economy to some of the exogenous shocks, Figure 4 provides a graphical representation of the model's key macrofinancial linkages, which will serve as a useful roadmap for the interpretation of the impulse responses in Section 4. 
Figure 4. Overview of the Model's Key Macrofinancial Linkages

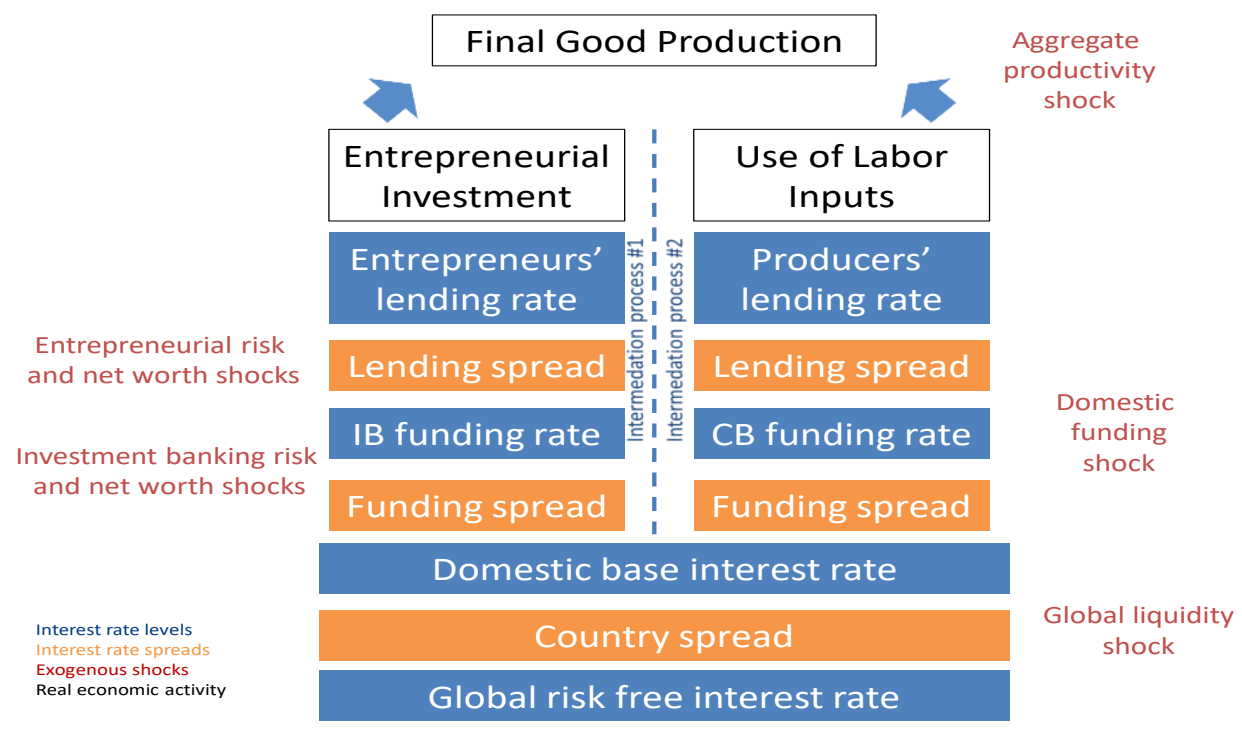

Source: Author's modeling. 
Table 3. Parameterization of the Model

\begin{tabular}{|c|c|c|c|}
\hline Parameter & Value & Description & Source \\
\hline$\beta$ & 0.99 & Discount factor & Hirakata et al. (2009) \\
\hline$\delta$ & 0.025 & Capital depreciation rate & Hirakata et al. (2009) \\
\hline$\alpha$ & 0.35 & Capital share in final goods production & Hirakata et al. (2009) \\
\hline$R$ & $0.99^{-1}$ & Risk-free rate & Hirakata et al. (2009) \\
\hline$\eta$ & 3 & Elasticity of leisure & Hirakata et al. (2009) \\
\hline$\chi$ & 0.3 & Utility weight on leisure & Hirakata et al. (2009) \\
\hline$\kappa$ & 2.5 & Investment adjustment cost & Hirakata et al. (2009) \\
\hline$\rho_{a}, \rho_{\sigma^{F},} \rho_{\sigma^{E}}$ & 0.85 & $\begin{array}{l}\text { Persistence of productivity and risk } \\
\text { shocks }\end{array}$ & Hirakata et al. (2009) \\
\hline $\bar{\sigma}^{F}$ & 0.107366 & $\begin{array}{l}\text { Standard deviations of risk shocks in } \\
\text { investment banking at steady state }\end{array}$ & Hirakata et al. (2009) \\
\hline $\bar{\sigma}^{E}$ & 0.312687 & $\begin{array}{l}\text { Standard deviations of entrepreneurial } \\
\text { sector risk shocks at steady state }\end{array}$ & Hirakata et al. (2009) \\
\hline $\bar{\sigma}^{a}$ & 0.0098 & $\begin{array}{l}\text { Standard deviations of total factor } \\
\text { productivity shocks }\end{array}$ & Hirakata et al. (2011) \\
\hline$\mu^{F}$ & 0.033046 & Bankruptcy costs in investment banking & Hirakata et al. (2009) \\
\hline$\mu^{E}$ & 0.013123 & $\begin{array}{l}\text { Bankruptcy costs in the entrepreneurial } \\
\text { sector }\end{array}$ & Hirakata et al. (2009) \\
\hline$\gamma^{F}$ & 0.963286 & Survival rate in investment banking & Hirakata et al. (2009) \\
\hline$\gamma^{F}$ & 0.983840 & Survival rate in the entrepreneurial sector & Hirakata et al. (2009) \\
\hline$\Omega^{F}$ & 0.01 & Investment banks' share of labor input & Ueda (2012) \\
\hline$\Omega^{E}$ & 0.01 & Entrepreneurs' share of labor input & Ueda (2012) \\
\hline$\psi_{g}$ & 0.0001 & $\begin{array}{l}\text { Debt elastic interest rate parameter for the } \\
\text { domestic base interest rate level }\end{array}$ & $\begin{array}{l}\text { Schmitt-Grohé and Uribe } \\
(2003)\end{array}$ \\
\hline $\bar{d}$ & 0.007 & $\begin{array}{l}\text { Household debt to GDP ratio at steady } \\
\text { state }\end{array}$ & Cecchetti et al. (2011) \\
\hline$\rho_{\mu^{g}}$ & 0.85 & Persistence of the global liquidity shock & \\
\hline$\sigma_{\mu} g$ & 0.056 & $\begin{array}{l}\text { Standard deviation of the global liquidity } \\
\text { shock }\end{array}$ & Garcia-Cicco et al. (2010) \\
\hline$\sigma_{N F}$ & 0.01 & $\begin{array}{l}\text { Standard deviation of net worth shock in } \\
\text { investment banking }\end{array}$ & \\
\hline$\sigma_{N E}$ & 0.01 & $\begin{array}{l}\text { Standard deviation of net worth shock in } \\
\text { the entrepreneurial sector }\end{array}$ & \\
\hline$\rho_{\sigma^{N F},} \rho_{\sigma^{N E}}$ & 0.85 & $\begin{array}{l}\text { Persistence of net worth shock in } \\
\text { investment banking and the } \\
\text { entrepreneurial sector }\end{array}$ & Same persistence as for others. \\
\hline$\psi_{d}$ & 0.2 & $\begin{array}{l}\text { Balance sheet elastic interest rate } \\
\text { parameter for the commercial banks }\end{array}$ & $\begin{array}{l}\text { Average quarterly historical } \\
\text { TED spread of roughly } 60 \mathrm{bps} \text {. }\end{array}$ \\
\hline $\bar{L}$ & 3.00 & Commercial bank assets at steady state & \\
\hline$\rho_{\mu^{d}}$ & 0.85 & Persistence of the money market shock & Same persistence as for others. \\
\hline$\sigma_{\mu^{d}}$ & 0.1 & $\begin{array}{l}\text { Standard deviation of the money market } \\
\text { shock }\end{array}$ & 250 bps. TED spread increase. \\
\hline$\varphi^{R R}$ & 0.75 & Required reserve ratio & $\begin{array}{l}300 \mathrm{bps} \text {. lending to funding } \\
\text { spread. }\end{array}$ \\
\hline
\end{tabular}

Sources: Various (mentioned above).

CInternational Monetary Fund. Not for Redistribution 


\section{A. Risk Shock in the Entrepreneurial Sector}

Figures 5 portrays the equilibrium responses (i.e., deviations from steady state) to increased risk in the domestic entrepreneurial sector. The first thing to note is that the domestic base interest rate level declines, which plays an important role in causing consumption to increase and mitigate the otherwise contractionary effects of this shock. At first, this is surprising, but actually this reflects a common feature of real business cycle models with financial frictions. When financial shocks are transmitted in such models, they interfere with intertemporal substitution and due to the simple and frictionless set-up of the real economy, current consumption relative to future consumption (i.e., the real interest rate) declines, inducing increased consumption. This would not necessarily take place in a more realistic set-up with nominal rigidities and monetary policy based on a traditional Taylor rule, as these factors would dampen the real interest rate response. However, the focus in this paper is on the interaction between credit intermediation to the corporate sector through two processes including a number of interest rate spreads, on the one hand, and investment and production, on the other.

Figure 5 shows that as riskiness in the entrepreneurial sector increases, entrepreneurs' borrowing rate goes up, as investment banks' increase the spread on those loans relative to their own funding costs. This reaction is due to the fact that as riskiness increases, bankruptcies among entrepreneurs increase as a larger share of investment projects fail to attain sufficient returns to repay debt. As a result, the price of capital falls, entrepreneurs' net worth declines, and their leverage increases, resulting in a higher external finance premium. Hence, entrepreneurial investment activity falls, leading to further decreases in the price of capital, and tightening of credit constraints through the aforementioned dynamics. This amplification of shocks through credit frictions is why models with such features were generally referred to as financial accelerator models.

This shock originates in the entrepreneurial sector, and works its way through the former financial intermediation process to affect investment, and thereby production. Looking at the reaction in the latter financial intermediation process, movements in commercial banks' funding and lending rate seem to be reflect the fall in the domestic base interest rate level (discussed above), and the reaction in interest rate spreads is very muted. However, working capital loans decrease as demand for labor decreases alongside less investment and production. Hence, this is an example of the interaction between the two processes of financial intermediation, which in this case seem to first and foremost work their way through real economy linkages in aggregate production. Other types of macrofinancial linkages, through which the two intermediation processes will interact, will become apparent when other shocks will be discussed below.

Finally, a positive shock would have had the opposite effects, making the model able to produce qualitative boom-bust behavior around the steady state, although coming short from having the capacity to yield truly destabilizing dynamics. 
Figure 5. Impulse Responses to a Risk Shock in the Entrepreneurial Sector

Panel A. The Shock and Effects on Domestic Liquidity Provision
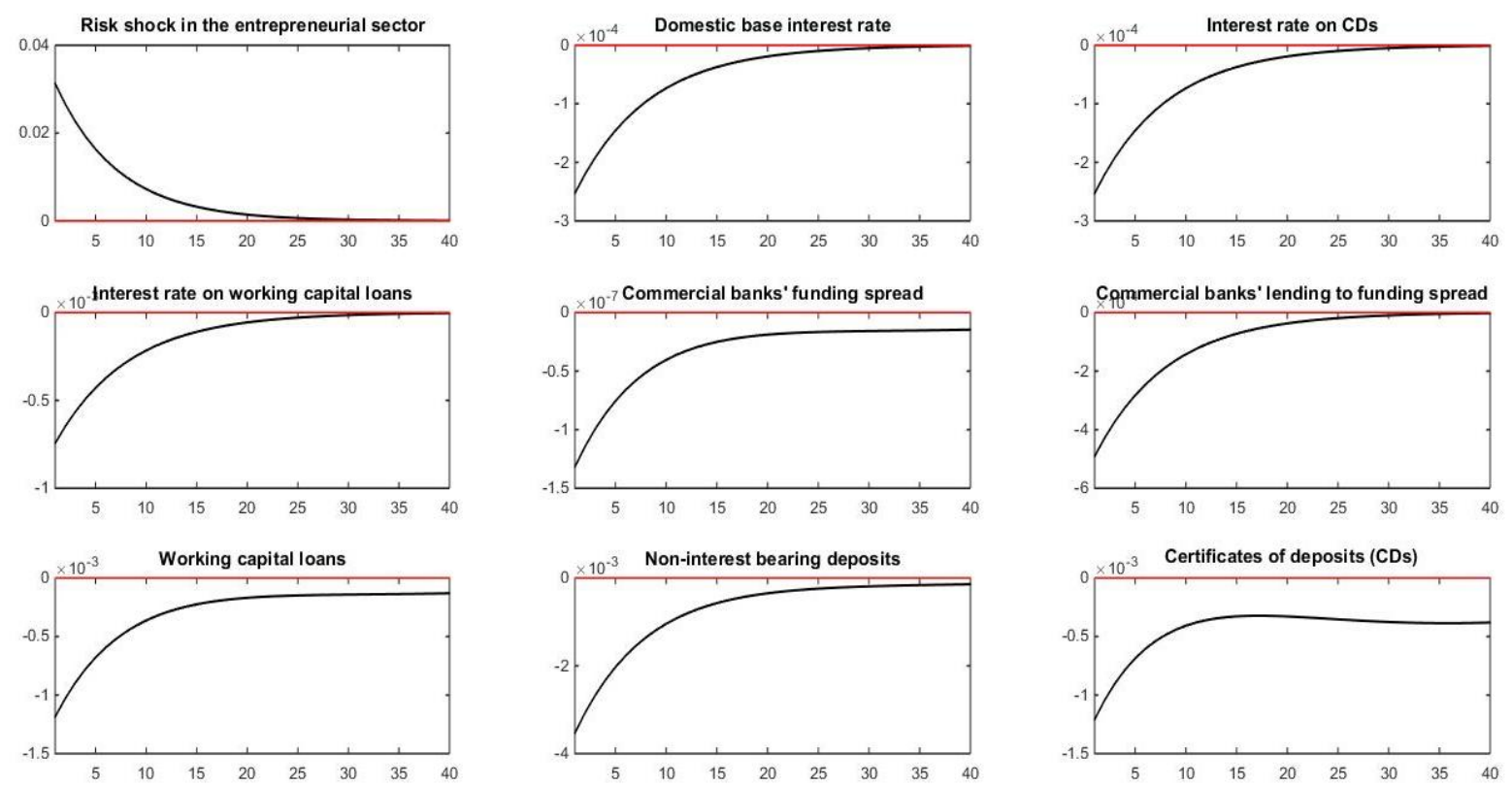

Panel B. The Effects on Cross-Border Credit Intermediation
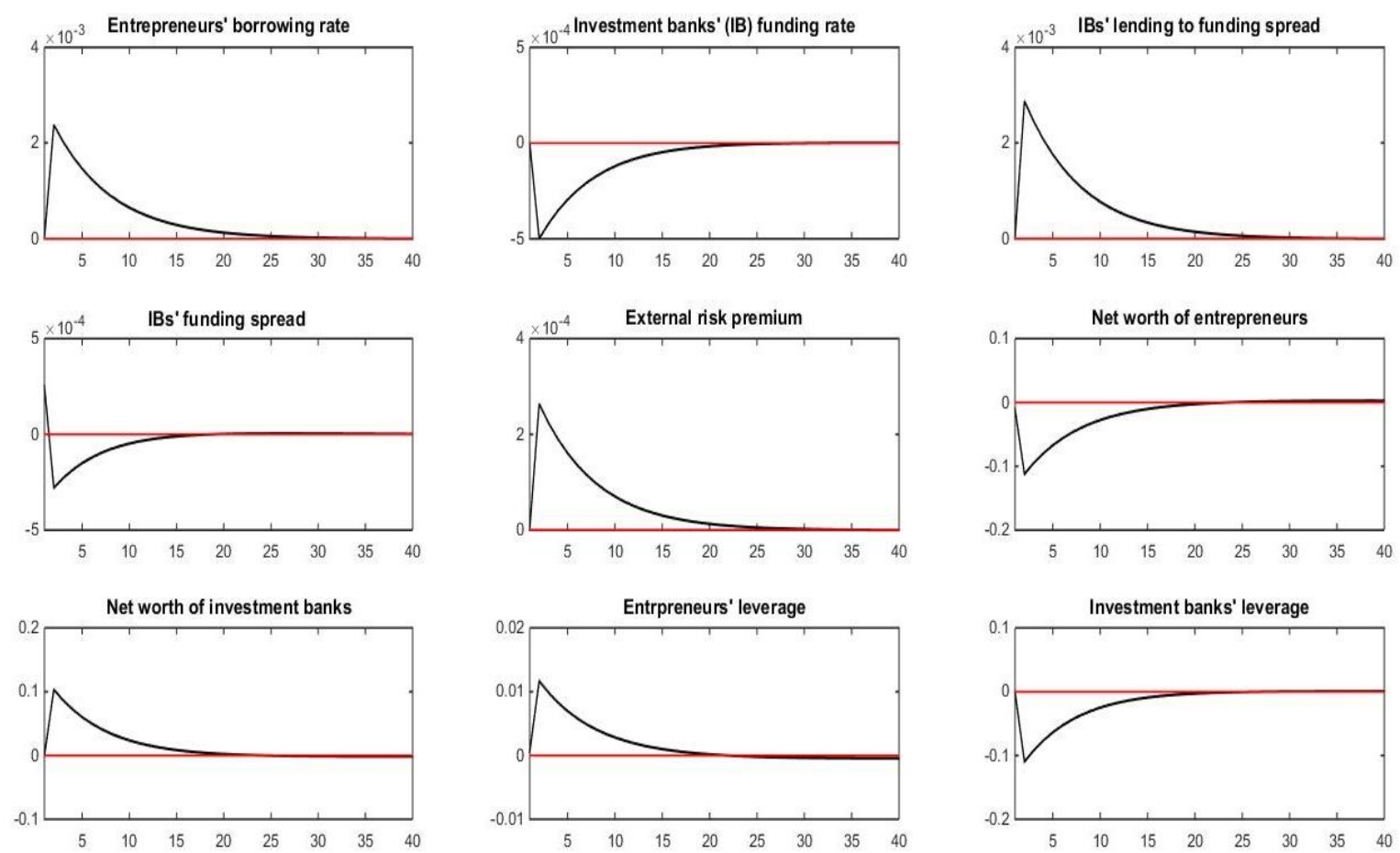
Figure 5. Impulse Responses to a Risk Shock in the Entrepreneurial Sector (concluded)

Panel C. The Effects on the Real Economy
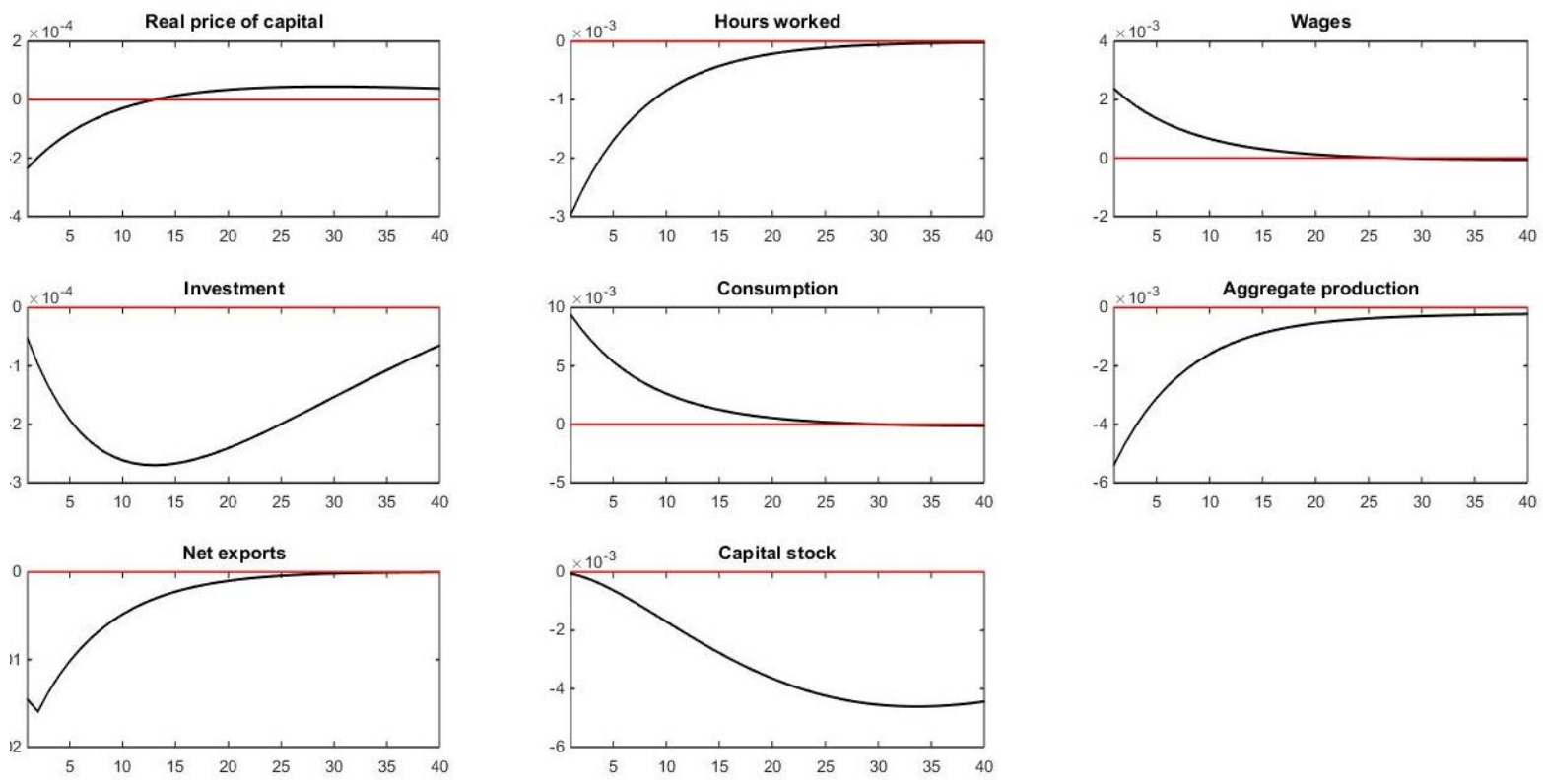

Source: Author's own model simulations.

\section{B. Risk Shock in Investment Banking}

The effects of a risk shock taking place in investment banking is shown in Figure 6. There are three important interrelated differences between the effects of a risk shock in investment banking compared to its previously discussed entrepreneurial counterpart.

First, in contrast to the increase in entrepreneurs' borrowing rate as a result of a risk shock in their own sector, investment banks' funding rate decreases after they experience a negative sectoral risk shock. This reflects that the investment banks' funding rate reaction is dominated by the decline in the base interest rate level. This again reflects that the investment banks receive their funds from global banks at a spread over the base interest rate, while entrepreneurs' borrowing cost include an additional spread due to the extra step of intermediating the funds through the investment banks.

Second, as the effects of increased riskiness in investment banking work their way across the credit market and interact with the real economy (Figure 6), investment banks' leverage declines instead of increasing as in the case of entrepreneurs in Figure 5. This also reflects the difference positions of the two sectors in the intermediation process, as well as their specific balance sheet characteristics. Investment banks are the main actors in this former intermediation process in the model, such that they can affect key parameters in the interlinked credit contracts, resulting in a redistribution of losses across sectors. Entrepreneurs, however, are the ultimate borrowers in this credit process and are not in a position to mitigate the effects of a negative shock in the same manner. As a result of a negative risk shock, investment banks increase the spread between their lending and funding 
rate, which supports their own net worth (also helped by the direct decline in their funding rate which dominates their increased funding spread), but undermines the financial position of entrepreneurs. As a result, the investment banks deleverage, which is particularly important for them as they operate with more leverage than the entrepreneurs. The model's capacity to produce sectoral leverage dynamics of this kind, is discussed further below.

A final important distinction between the two risk shocks is that the macroeconomic effects of a shock originating in investment banking are considerably larger compared to when they originate in the corporate sector. Hence, the effects that work their way across the real economy and towards commercial banks' domestic liquidity provision is also stronger, as reflected in a larger drop in working capital loans. This sizeable difference in macroeconomic effects also reflects the aforementioned interrelated characteristics that investment banks are highly leverage institutions that due to their importance in the credit intermediation process can strongly affect the propagation and acceleration of negative shocks, both across sectors, aggregate production, and the other financial intermediation process.

These two risk shocks therefore provide important insight into the workings of model. Clearly there are important differences and interactions between the two sectors, providing preliminary evidence supportive of the modeling approach takin with regard to the credit market. In particular, it seems promising that the model gives raise to procyclical leverage dynamics resulting from investment bank behavior within the model. This feature has been emphasized in a number of papers, in particular, by Adrian and Shin $(2009,2010,2011)$.

Figure 6. Impulse Responses to a Risk Shock in Investment Banking

Panel A. The Shock and Effects on Domestic Liquidity Provision
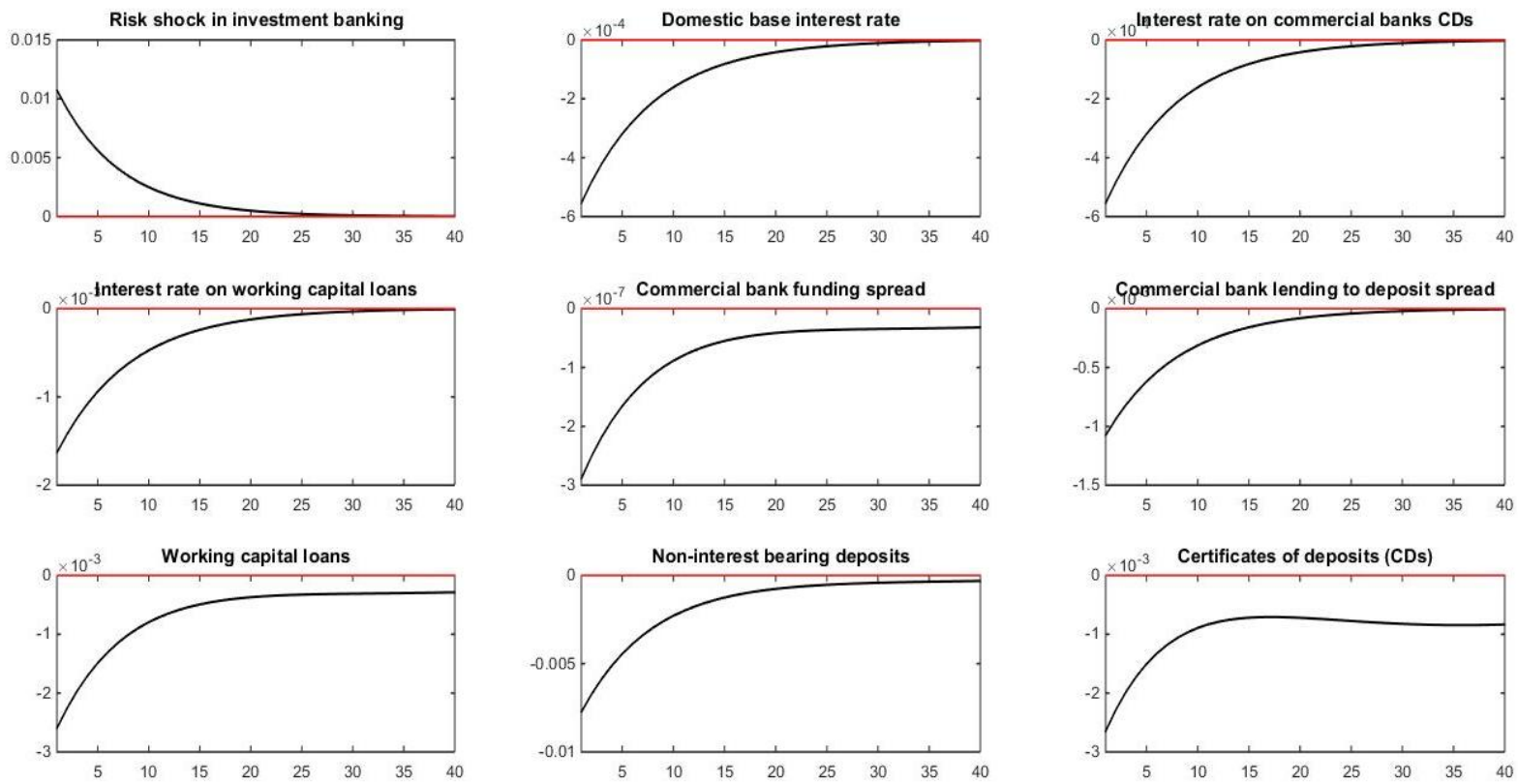
Panel B. The Effects on Cross-Border Credit Intermediation
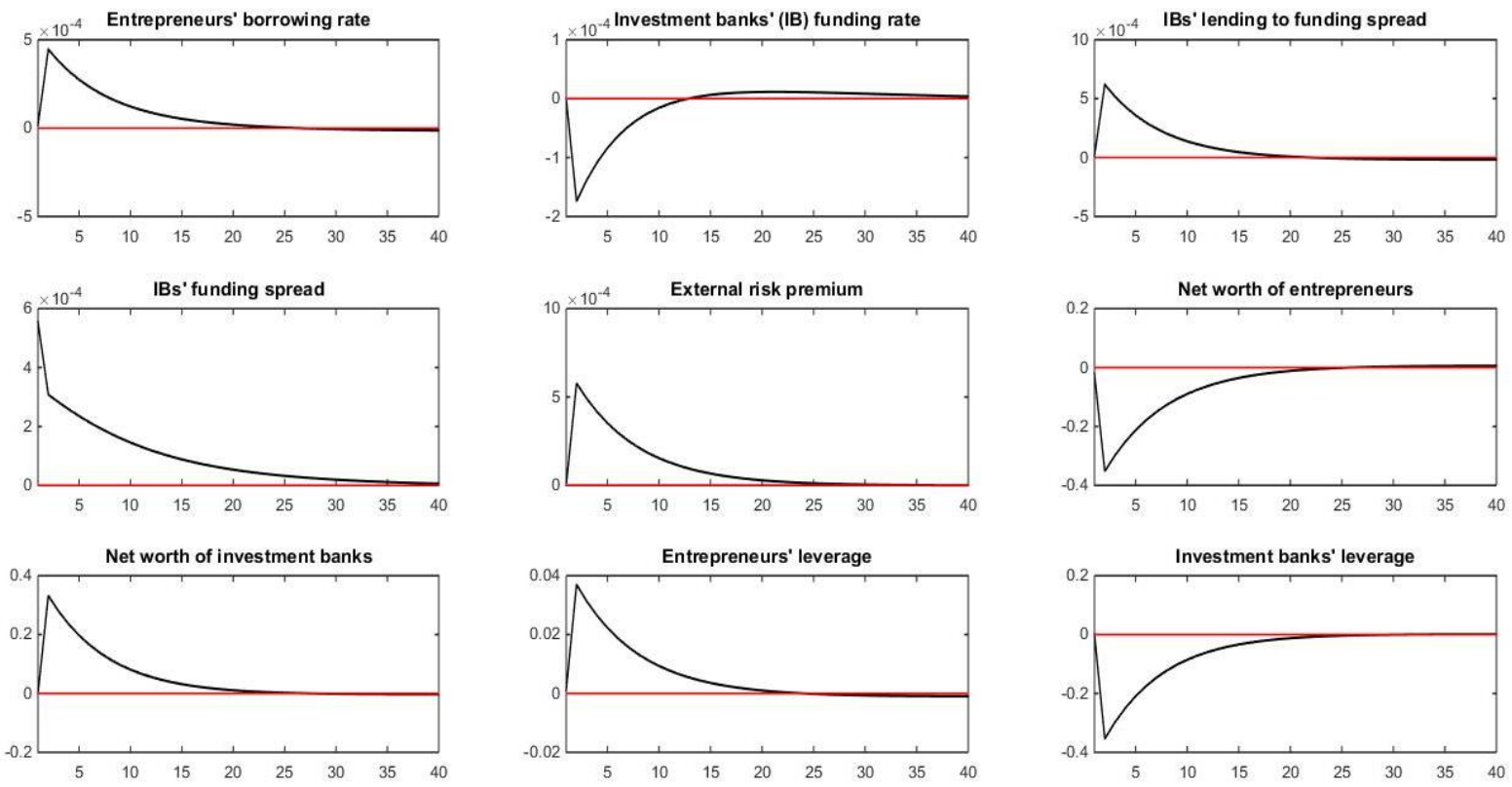

Panel C. The Effects on the Real Economy
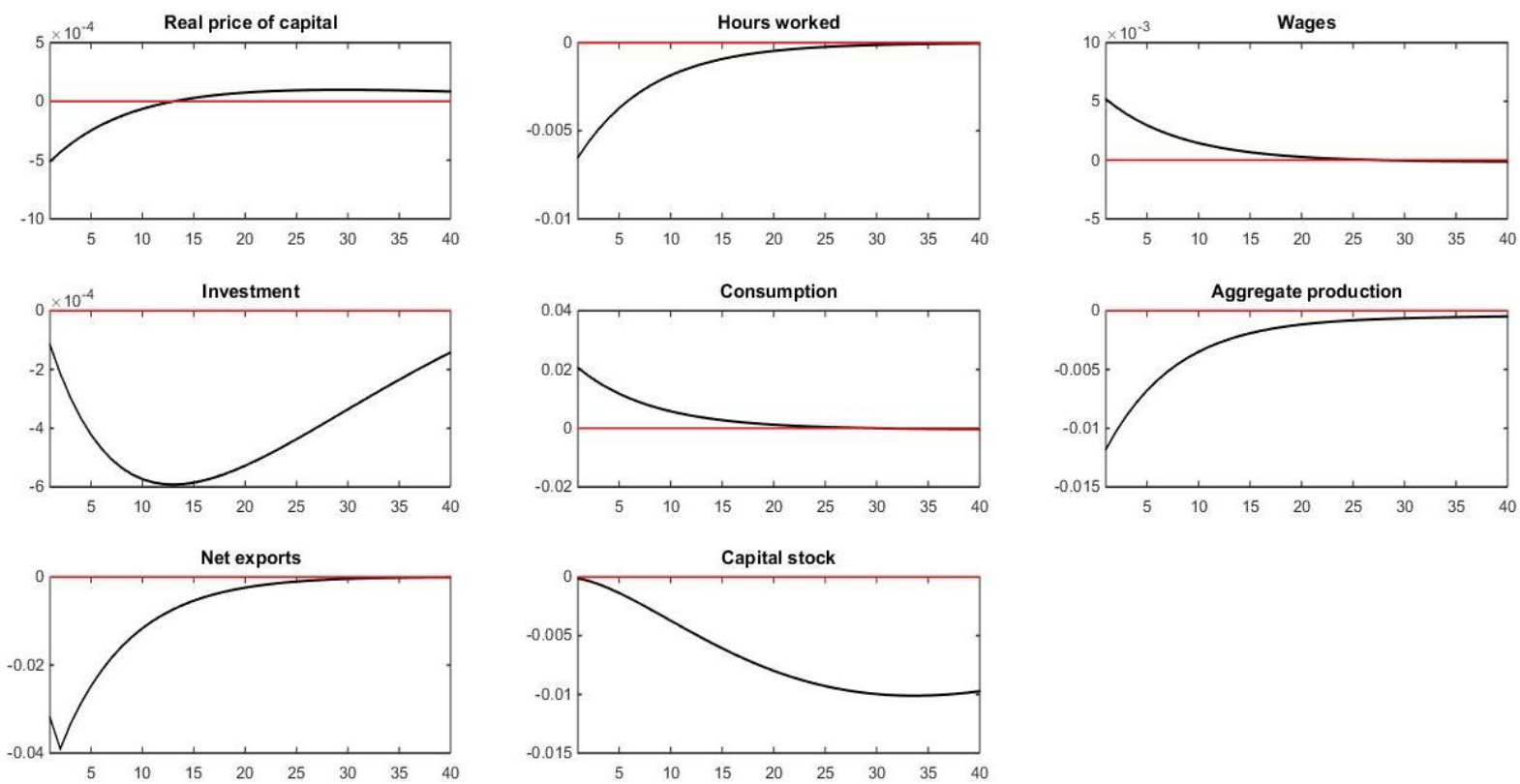

Source: Author's own model simulations. 


\section{Domestic Money Market Shock}

Figure 7 shows the effects of an adverse domestic liquidity shock in money markets, affecting the terms of commercial bank funding. Indeed, the banks' funding spread on the market increases and they respond by increasing their lending to funding spread (more than one-toone for their balance sheet constraint to hold). This results in balance sheet deleveraging in the sense that the commercial banks' assets and liabilities shrink. Importantly, working capital loans decrease, as do labor usage and aggregate production through this working capital channel.

The dynamic response in the other financial intermediation process is interesting, especially in light of the discussion above in relation to risk shocks in the two credit market participants' sectors. The shock considered here originated in the domestic money market where neither investment banks nor entrepreneurs are assumed to participate. Hence, the effects of the shocks reach these sectors through the effect that the working capital channels has on investment via its effect on aggregate production. This is different from the risk shock scenarios where the effects were first transmitted across the interlinked credit contracts, and then affected the real economy. As shown in Figure 7, entrepreneurs respond to the contractionary effects on investment activity by deleveraging, which leads to a decrease in the investment banks' lending to funding spread, causing their net worth to decline. Therefore, the fall in investment demand from entrepreneurs causes problems for the leveraged investment banks and, in contrast to the risk shocks, their capacity to propagate their problems onto the entrepreneurs is not the same.

\section{Global Liquidity Shock}

Figure 8 shows the impulse responses to a global liquidity shock, which is the only shock that directly affects the domestic base interest rate level. In contrast to the fall in the base interest rate level observed in previous domestic shocks, it increases following an adverse global liquidity shock, and now both financial intermediation processes are affected at once. Interestingly, both the commercial and investment banks' funding spread actually fall on impact, such that the raise in the base interest rate is not fully transmitted into their funding rate, which is somewhat puzzling. These banks are therefore to some extent guarded against global shocks, but nevertheless, both intermediary types respond to this adverse shock by increasing their lending to funding spreads. The result is hence that contractionary macroeconomic effects work their way across both intermediation processes, and onwards through the working capital and investment channels.

In case of a shock where the ease of financing in global financial system is enhanced, the opposite result would arise, with production being supported by enhanced financial intermediation on both parts of the credit market. Hence, the model captures some parts of possible risks associated with international capital flows and domestic financial conditions (Jeanne and Korinek, 2010, Korinek, 2011, Rey, 2013, Cerutti et al., forthcoming, Brunnermeier and Sannikov, 2015, and Central Bank of Iceland, 2017). 
Figure 7. Impulse Responses to a Domestic Money Market Shock

Panel A. The Shock and Effects on Domestic Liquidity Provision
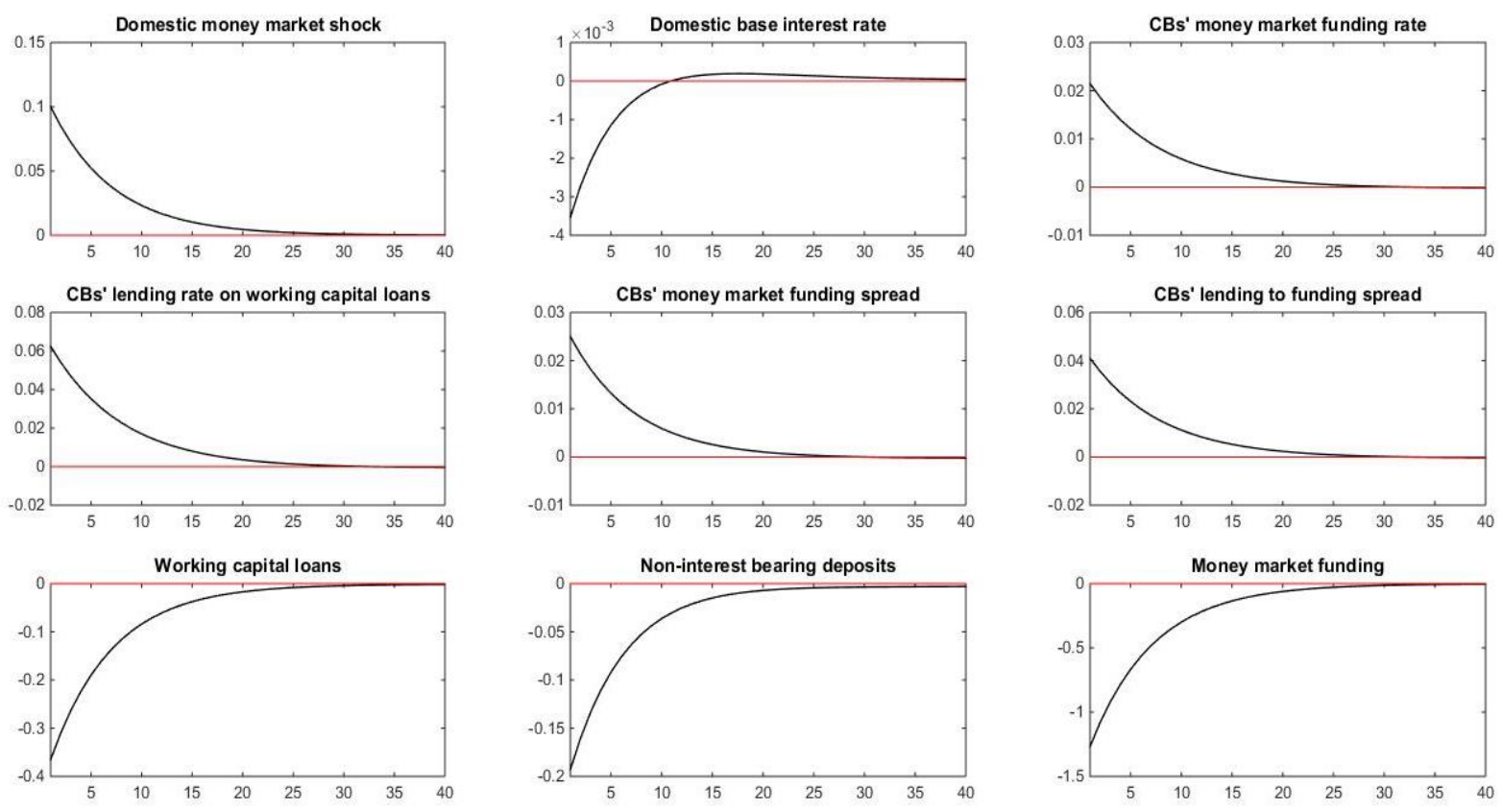

Panel B. The Effects on Cross-Border Credit Intermediation
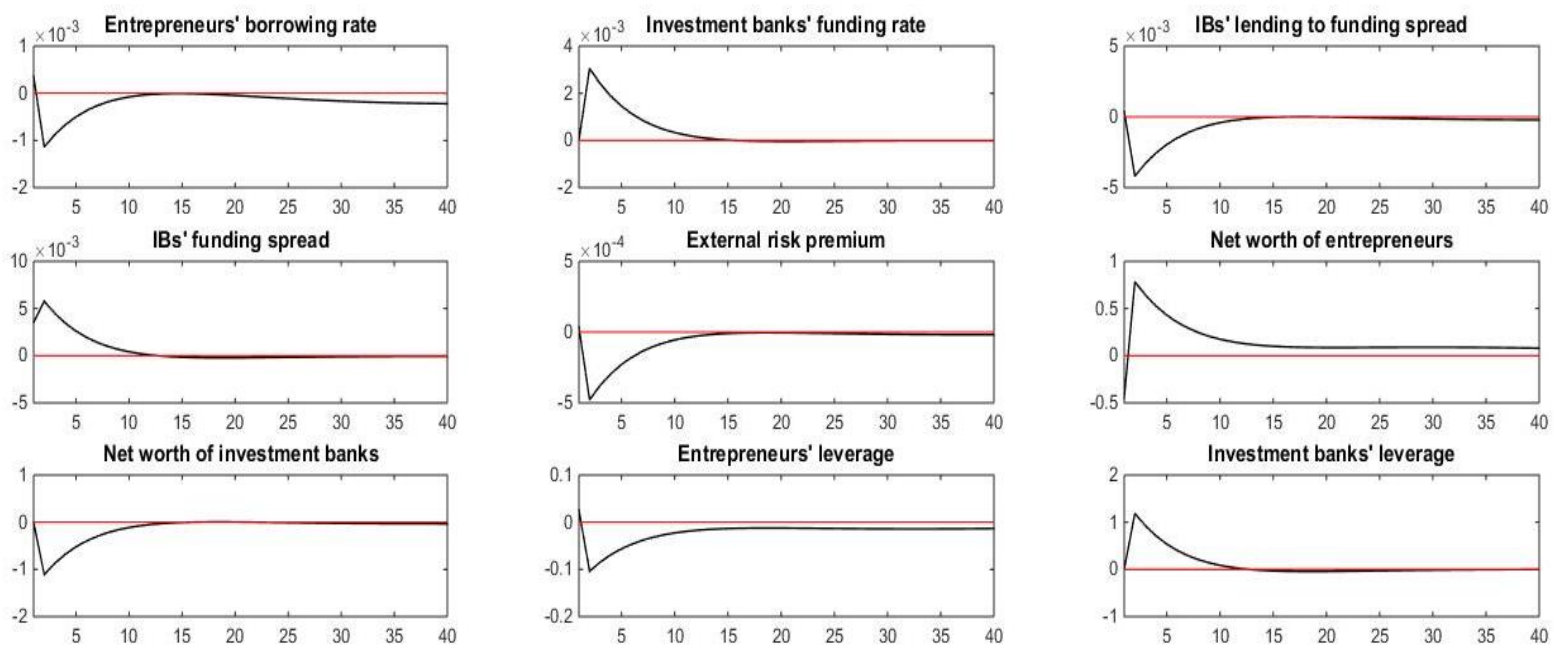
Figure 7. Impulse Responses to a Domestic Money Market Shock

Panel C. The Effects on the Real Economy
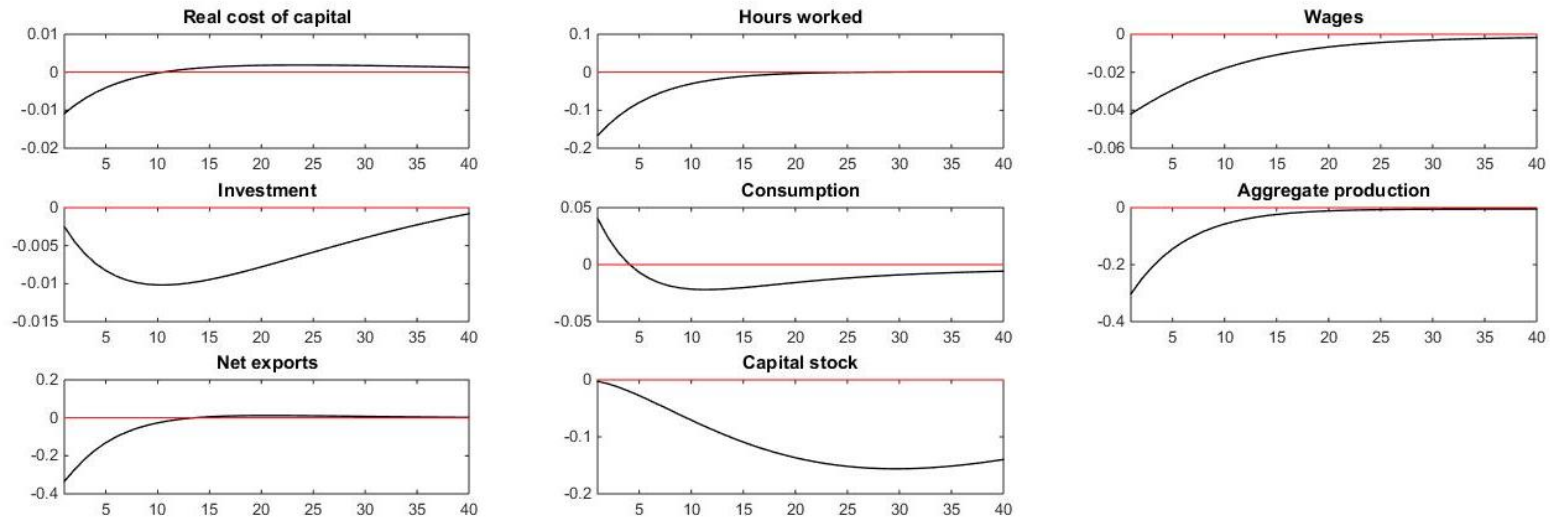

Source: Author's own model simulations.

Figure 8. Impulse Responses to a Global Liquidity Shock

Panel A. The Shock and Effects on Domestic Liquidity Provision
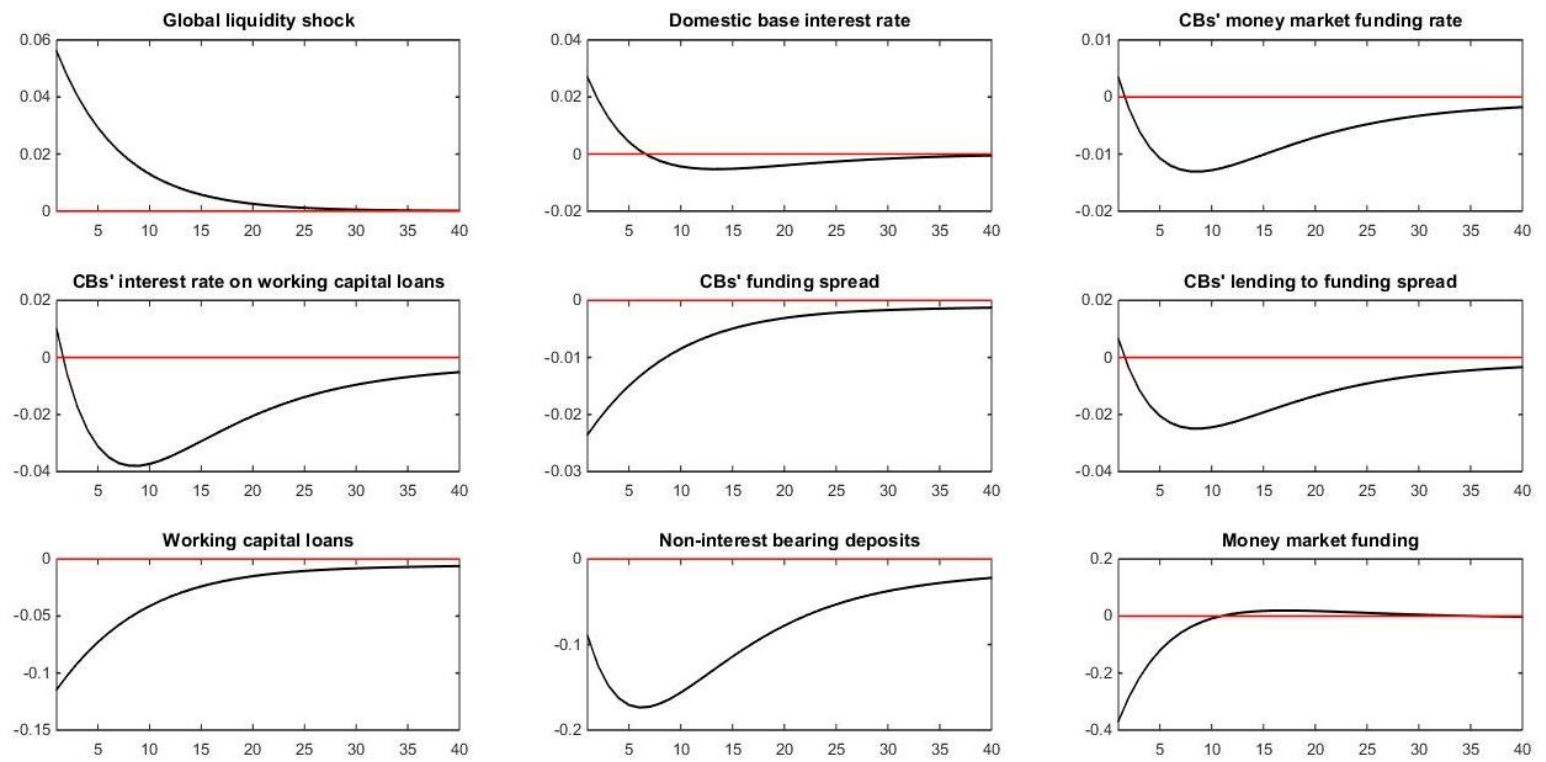
Figure 8. Impulse Responses to a Global Liquidity Shock (concluded)

Panel B. The Effects on Cross-Border Credit Intermediation
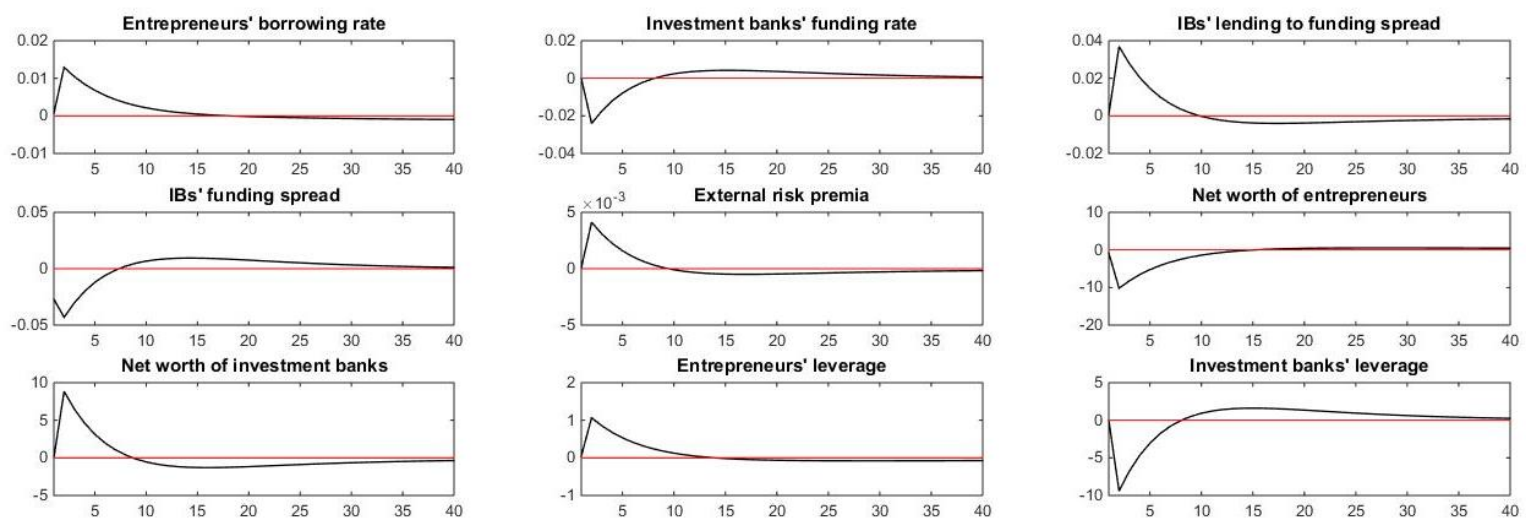

Panel C. The Effects on the Real Economy
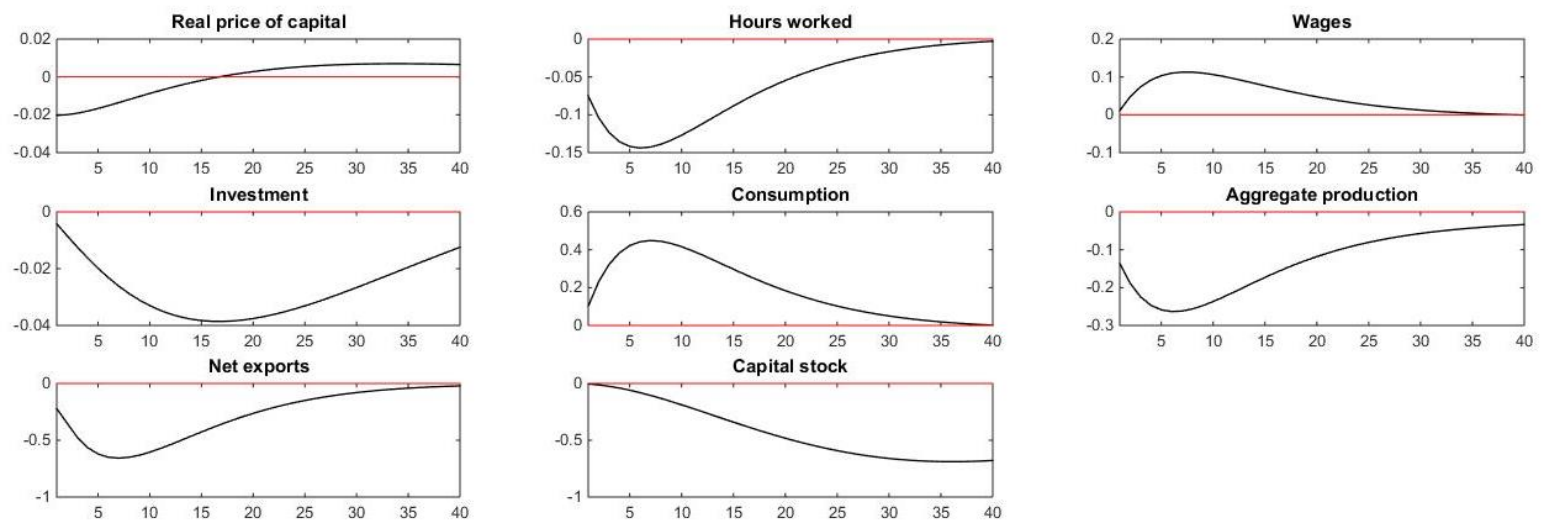

Source: Author's own model simulations.

\section{Conclusions}

In this paper, a small open economy DSGE model is developed where investment banks and commercial banks intermediate global and domestic liquidity to the corporate sector through two financial intermediation processes. In particular, global liquidity is intermediated by investment banks to entrepreneurs through interlinked credit contracts, that allow for asymmetric information and bankruptcies which give rise to interest rates and balance sheet relations through which the financial intermediation and the real economy interact. On the other hand, commercial banks intermediate domestic liquidity to cash-in-advance constrained final good producers. Hence, production within the economy depends on both financial intermediation processes as they enable funding and development of key production inputs. The richness of the credit market framework is reflected in the number of market participants, interest rate spreads, and shocks, as well as the diverse feedback and propagation mechanisms which the set-up gives rise to between the financial system and the real economy. 
The economic analysis of the model served to illuminate in a qualitative manner how the interconnectedness within the financial system and the macrofinancial linkages transmit shocks within the financial sector and across the real economy. The analysis showed that the model is qualitatively capable of producing a number of features in this regard, which have been emphasized in the literature.

First, the model has financial accelerator characteristics as risk shocks can give rise to boombust investment dynamics that are strengthened by the presence of investment banks and the interlinked credit contracts. This is unsurprising as the Hirakata et al. $(2009,2016)$ is used as the underlying framework for one of the financial intermediation processes.

Second, in contrast to Hirakata et al. (2009, 2016), the model also includes another intermediation process, where on the one hand, there is a role for specific domestic money market pressures that propagate through the working capital channel to the rest of the model. On the other hand, there is also an important role for shocks of various kinds to interact across the two financial intermediation processes, which is a relatively rare feature in financial friction models. This can reflect common shocks (i.e., the global liquidity shock) affecting both investment and commercial banks, but also shocks originating in either of the two intermediation processes (e.g., risk shocks or domestic money market shocks) that propagate across the two processes via the real economy. Hence, the model provides a richer framework than many other financial friction models, including Bernanke et al. (1999) and Hirakata et al. $(2009,2016)$, both with regard to linkages within the financial system, global spillovers to the domestic financial system, and the macrofinancial linkages between the real and financial sectors.

Third, there is a role for a central bank as a liquidity regulator in the model in the sense that commercial banks are assumed to be regulated, while investment banks and saving funds are unregulated. This is a realistic assumption for many small advanced economies. Another difference between commercial and investment banks in the model is that the costly state verification framework is applied to the riskier investment banking activity that operates across borders and involves funding risky entrepreneurial investments, while a simpler approach is applied to model the more traditional and purely domestic liquidity services of commercial banks.

The qualitative capacity of the model to produce and analyze important macrofinancial features, such as procyclical leverage dynamics of investment banks, money market pressures, global liquidity spillovers, and a wide range of financial and macroeconomic interlinkages (including through investment and working capital channels), indicates that this approach may deserve further examination and extensions. This would include analyzing its capacity to provide reasonable quantitative dynamics and guidance on implementation of macroeconomic and financial sector policies, as well as even capital flow management measures. 


\section{Appendix I. Solution to the Investment Banks' Maximization Problem}

The monopolistic domestic investment bank maximizes its expected profits:

$$
\begin{aligned}
\max _{\bar{\omega}^{\mathrm{F}}, \bar{\omega}^{\mathrm{E}}, \mathrm{K}} & \sum_{\mathrm{s}^{t+1}} \pi\left(\mathrm{s}^{\mathrm{t}+1} \mid \mathrm{s}^{\mathrm{t}}\right)[1 \\
& \left.-\Gamma^{\mathrm{F}}\left(\bar{\omega}^{\mathrm{F}}\left(\mathrm{s}^{\mathrm{t}+1} \mid \mathrm{s}^{\mathrm{t}}\right)\right)\right]\left[1+\mathrm{R}^{\mathrm{F}}\left(\mathrm{s}^{\mathrm{t}+1} \mid \mathrm{s}^{\mathrm{t}}\right)\right]\left[\mathrm{Q}\left(\mathrm{s}^{\mathrm{t}}\right) \mathrm{K}_{\mathrm{i}}\left(\mathrm{s}^{\mathrm{t}}\right)-\mathrm{N}_{\mathrm{i}}^{\mathrm{E}}\left(\mathrm{s}^{\mathrm{t}}\right)\right]
\end{aligned}
$$

where $\pi\left(s^{t+1} \mid s^{t}\right)$ is the probability weight for state $s^{t+1}$ given state $s^{t+1-1},[1-$ $\left.\Gamma^{\mathrm{F}}\left(\bar{\omega}^{\mathrm{F}}\left(\mathrm{s}^{\mathrm{t}+1} \mid \mathrm{s}^{\mathrm{t}}\right)\right)\right]$ represents the share of investment banks' earnings kept by the institutions themselves, $\left[1+\mathrm{R}^{\mathrm{F}}\left(\mathrm{s}^{\mathrm{t}+1} \mid \mathrm{s}^{\mathrm{t}}\right)\right]$ is the average return on the FE contracts, and $\left[Q\left(s^{t}\right) K_{i}\left(s^{t}\right)-\right.$ $\left.N_{i}^{E}\left(s^{t}\right)\right]$ the amount lent to entrepreneurs. This maximization is solved subject to the participation constraints of the entrepreneurs and the global banks, respectively:

$$
\begin{gathered}
\left\{\left(1-\Gamma_{t}^{E}\left(\bar{\omega}_{j_{i}}^{E}\left(s^{t+1} \mid s^{t}\right)\right)\right\}\left(1+R^{E}\left(s^{t+1} \mid s^{t}\right)\right) Q\left(s^{t}\right) K_{j_{i}}\left(s^{t}\right)\right. \\
\geq\left(1+R^{E}\left(s^{t+1} \mid s^{t}\right)\right) N_{j_{i}}^{E}\left(s^{t}\right) \forall j_{i}, s^{t+1} \mid s^{t} \\
\left\{\Gamma_{t}^{F}\left(\bar{\omega}_{i}^{F}\left(s^{t+1} \mid s^{t}\right)\right)-\mu^{F} G_{t}^{F}\left(\bar{\omega}_{i}^{F}\left(s^{t+1} \mid s^{t}\right)\right)\right\}\left(1+R^{F}\left(s^{t+1} \mid s^{t}\right)\right)\left[Q\left(s^{t}\right) K_{i}\left(s^{t}\right)\right. \\
\left.-N_{i}^{E}\left(s^{t}\right)\right] \geq\left(1+R\left(s^{t}\right)\right)\left[Q\left(s^{t}\right) K_{i}\left(s^{t}\right)-N_{i}^{E}\left(s^{t}\right)-N_{i}^{F}\left(s^{t}\right)\right]
\end{gathered}
$$

Here the focus is on the case where these participation constraints hold with equality. For the entrepreneurs, this implies that their share of returns from investing their net equity and borrowed funds are equal to what they would receive from investing only their equity. In equation (A1.2) above, $\left\{\left(1-\Gamma_{t}^{E}\left(\bar{\omega}_{j_{i}}^{E}\left(s^{t+1} \mid s^{t}\right)\right)\right\}\right.$, represents the expected share of entrepreneurial earnings kept by the entrepreneurs according to the FE contract, and $\Gamma_{t}^{E}\left(\bar{\omega}_{j_{i}}^{E}\left(s^{t+1} \mid s^{t}\right)\right)$, represents the gross share of entrepreneurial earnings received by the investment banks according to the same contract. The participation constraint of the global banks (equation A1.3) reflects that their net earnings from the GF contract must equal their opportunity cost of lending, $\left(1+R\left(s^{t}\right)\right)$. The expression $\left\{\Gamma_{t}^{F}\left(\bar{\omega}_{i}^{F}\left(s^{t+1} \mid s^{t}\right)\right)-\right.$ $\left.\mu^{F} G_{t}^{F}\left(\bar{\omega}_{i}^{F}\left(s^{t+1} \mid s^{t}\right)\right)\right\} \equiv \Phi^{F}\left(\bar{\omega}^{F}\left(s^{t+1} \mid s^{t}\right)\right.$ represents the net share of investment banks' earnings going to global banks according to the GF contract. Making use of the definition of the expected return on the loans to entrepreneurs, $\left(1+R^{F}\left(s^{t+1} \mid s^{t}\right)\right)$ in equation (8) to rewrite the investment banks' expected profits as:

$$
\begin{aligned}
\max _{\bar{\omega}^{\mathrm{F}}, \bar{\omega}^{\mathrm{E}}, \mathrm{K}} \sum_{\mathrm{s}^{t+1}} \pi\left(\mathrm{s}^{\mathrm{t}+1} \mid \mathrm{s}^{\mathrm{t}}\right)[1 \\
\left.-\Gamma^{\mathrm{F}}\left(\bar{\omega}^{\mathrm{F}}\left(\mathrm{s}^{\mathrm{t}+1} \mid \mathrm{s}^{\mathrm{t}}\right)\right)\right] \Phi_{j_{i, t}}^{F}\left(\bar{\omega}_{j_{i}}^{F}\left(s^{t+1} \mid s^{t}\right)\right)(1 \\
\left.\quad+R^{E}\left(s^{t+1} \mid s^{t}\right)\right) Q\left(s^{t}\right) K_{i}\left(s^{t}\right)
\end{aligned}
$$

where $\Phi_{j_{i, t}}^{E}\left(\bar{\omega}_{j_{i}}^{E}\left(s^{t+1} \mid s^{t}\right)\right)$ represents the net share of entrepreneurial earnings going to the investment banks according to the FE contract. The global banks' participation constraint is rewritten by replacing $\left(1+R^{F}\left(s^{t+1} \mid s^{t}\right)\right)$ and using $\Phi^{F}\left(\bar{\omega}^{F}\left(s^{t+1} \mid s^{t}\right)\right.$ instead of $\left\{\Gamma_{t}^{F}\left(\bar{\omega}_{i}^{F}\left(s^{t+1} \mid s^{t}\right)\right)-\mu^{F} G_{t}^{F}\left(\bar{\omega}_{i}^{F}\left(s^{t+1} \mid s^{t}\right)\right)\right\}$. Hence, the Lagrangian function becomes: 


$$
\begin{aligned}
& \mathrm{L}\left(\bar{\omega}^{\mathrm{F}}, \bar{\omega}^{\mathrm{E}}, \mathrm{K}\right) \\
& \begin{aligned}
\sum_{\mathrm{s}^{t+1}} \pi\left(\mathrm{s}^{\mathrm{t}+1} \mid s^{\mathrm{t}}\right)\left[1-\Gamma^{\mathrm{F}}\left(\bar{\omega}^{\mathrm{F}}\left(s^{\mathrm{t}+1} \mid s^{\mathrm{t}}\right)\right)\right] \Phi_{j_{i, t}}^{E}\left(\bar{\omega}_{j_{i}}^{E}\left(s^{t+1} \mid s^{t}\right)\right)\left(1+R^{E}\left(s^{t+1} \mid s^{t}\right)\right) Q\left(s^{t}\right) K_{i}\left(s^{t}\right) \\
+\lambda^{1}\left\{\Phi ^ { F } \left(\bar{\omega}^{F}\left(s^{t+1} \mid s^{t}\right) \Phi_{j_{i, t}}^{E}\left(\bar{\omega}_{j_{i}}^{E}\left(s^{t+1} \mid s^{t}\right)\right)\left(1+R^{E}\left(s^{t+1} \mid s^{t}\right)\right) Q\left(s^{t}\right) K_{i}\left(s^{t}\right)-(1\right.\right. \\
\left.\left.\quad+R\left(s^{t}\right)\right)\left[Q\left(s^{t}\right) K_{i}\left(s^{t}\right)-N_{i}^{E}\left(s^{t}\right)-N_{i}^{F}\left(s^{t}\right)\right]\right\} \\
+\lambda^{2}\left[\left\{\left(1-\Gamma_{t}^{E}\left(\bar{\omega}_{j_{i}}^{E}\left(s^{t+1} \mid s^{t}\right)\right)\right\} Q\left(s^{t}\right) K\left(s^{t}\right)-N^{E}\left(s^{t}\right)\right]\right.
\end{aligned}
\end{aligned}
$$

The first-order-conditions of the maximization problem with regard to $\bar{\omega}^{\mathrm{F}}, \bar{\omega}^{\mathrm{E}}$ and $\mathrm{K}$, respectively, are given by:

$$
\begin{gathered}
\lambda^{1}=\frac{\sum_{s^{t+1}} \pi\left(s^{\mathrm{t}+1} \mid s^{\mathrm{t}}\right) \Gamma^{\prime \mathrm{F}}\left(\bar{\omega}^{\mathrm{F}}\left(\mathrm{s}^{\mathrm{t}+1} \mid \mathrm{s}^{\mathrm{t}}\right)\right)}{\Phi^{\prime F}\left(\bar{\omega}^{F}\left(s^{t+1} \mid s^{t}\right)\right.} \\
\sum_{\mathrm{s}^{t+1}} \pi\left(\mathrm{s}^{\mathrm{t}+1} \mid \mathrm{s}^{\mathrm{t}}\right)\left[1-\Gamma^{\mathrm{F}}\left(\bar{\omega}^{\mathrm{F}}\left(\mathrm{s}^{\mathrm{t}+1} \mid \mathrm{s}^{\mathrm{t}}\right)\right)\right] \Phi_{j_{i, t}^{\prime E}}^{\prime}\left(\bar{\omega}_{j_{i}}^{E}\left(s^{t+1} \mid s^{t}\right)\right)\left(1+R^{E}\left(s^{t+1} \mid s^{t}\right)\right) \\
+\lambda^{1} \Phi^{F}\left(\overline { \omega } ^ { F } ( s ^ { t + 1 } | s ^ { t } ) \Phi _ { j _ { i , t } } ^ { E } ( \overline { \omega } _ { j _ { i } } ^ { E } ( s ^ { t + 1 } | s ^ { t } ) ) \left(1+R^{E}\left(s^{t+1} \mid s^{t}\right)\right.\right. \\
-\lambda^{2} \Gamma^{\prime \mathrm{F}}\left(\bar{\omega}^{\mathrm{F}}\left(\mathrm{s}^{\mathrm{t}+1} \mid \mathrm{s}^{\mathrm{t}}\right)\right)=0 \\
\sum_{s^{t+1}} \pi\left(\mathrm{s}^{\mathrm{t}+1} \mid \mathrm{s}^{\mathrm{t}}\right)\left[1-\Gamma^{\mathrm{F}}\left(\bar{\omega}^{\mathrm{F}}\left(\mathrm{s}^{\mathrm{t}+1} \mid \mathrm{s}^{\mathrm{t}}\right)\right)\right] \Phi_{j_{i, t}}^{E}\left(\bar{\omega}_{j_{i}}^{E}\left(s^{t+1} \mid s^{t}\right)\right)\left(1+R^{E}\left(s^{t+1} \mid s^{t}\right)\right) \\
+\lambda^{1}\left[\Phi^{F}\left(\bar{\omega}^{F}\left(s^{t+1} \mid s^{t}\right) \Phi_{j_{i, t}}^{E}\left(\bar{\omega}_{j_{i}}^{E}\left(s^{t+1} \mid s^{t}\right)\right)\left(1+R^{E}\left(s^{t+1} \mid s^{t}\right)\right)-\left(1+R\left(s^{t}\right)\right)\right]\right. \\
+\lambda^{2}\left[1-\Gamma^{\mathrm{F}}\left(\bar{\omega}^{\mathrm{F}}\left(\mathrm{s}^{\mathrm{t}+1} \mid \mathrm{s}^{\mathrm{t}}\right)\right)\right]=0
\end{gathered}
$$

Inserting (A1.6) into (A1.7) and simplifying yields:

$$
\begin{aligned}
& \lambda^{2}= \\
& \frac{\sum_{s^{t+1}} \pi\left(s^{\mathrm{t}+1} \mid \mathrm{s}^{\mathrm{t}}\right)\left[1-\Gamma^{\mathrm{F}}\left(\bar{\omega}^{\mathrm{F}}\left(\mathrm{s}^{\mathrm{t}+1} \mid \mathrm{s}^{\mathrm{t}}\right)\right)\right] \Phi_{j_{i, t}^{\prime}}^{\prime}\left(\bar{\omega}_{j_{i}}^{E}\left(s^{t+1} \mid s^{t}\right)\right)\left(1+R^{E}\left(s^{t+1} \mid s^{t}\right)\right)}{\Gamma^{\prime} \mathrm{F}\left(\bar{\omega}^{\mathrm{F}}\left(\mathrm{s}^{\mathrm{t}+1} \mid \mathrm{s}^{\mathrm{t}}\right)\right)} \\
& +\frac{\left.\left.\sum_{\mathrm{s}^{t+1}} \pi\left(\mathrm{s}^{\mathrm{t}+1} \mid \mathrm{s}^{\mathrm{t}}\right)\right)\right] \Gamma^{\prime \mathrm{F}}\left(\bar{\omega}^{\mathrm{F}}\left(\mathrm{s}^{\mathrm{t}+1} \mid \mathrm{s}^{\mathrm{t}}\right)\right) \Phi^{F}\left(\bar{\omega}^{F}\left(s^{t+1} \mid s^{t}\right) \Phi_{j_{i, t}}^{\prime}\left(\bar{\omega}_{j_{i}}^{E}\left(s^{t+1} \mid s^{t}\right)\right)\left(1+R^{E}\left(s^{t+1} \mid s^{t}\right)\right)\right.}{\Gamma^{\prime \mathrm{F}}\left(\bar{\omega}^{\mathrm{F}}\left(\mathrm{s}^{\mathrm{t}+1} \mid \mathrm{s}^{\mathrm{t}}\right)\right) \Phi^{\prime F}\left(\bar{\omega}^{F}\left(s^{t+1} \mid s^{t}\right)\right.}
\end{aligned}
$$


Inserting into (A1.8) yields equation (14) in the main text, i.e.:

$$
\begin{gathered}
0=\sum \pi\left(s^{t+1} \mid s^{t}\right) \\
\left\{\left[1-\Gamma_{t}^{F}\left(\bar{\omega}_{i}^{F}\left(s^{t+1} \mid s^{t}\right)\right)\right] \Phi_{i, t}^{F}\left(s^{t+1} \mid s^{t}\right)\left[1+R^{E}\left(s^{t+1} \mid s^{t}\right)\right]\right\} \\
+\frac{\Gamma_{t}^{\prime F}\left(\bar{\omega}_{i}^{F}\left(s^{t+1} \mid s^{t}\right)\right)}{\Phi_{i, t}^{\prime F}\left(\bar{\omega}_{i}^{F}\left(s^{t+1} \mid s^{t}\right)\right)} \Phi_{i, t}^{F}\left(s^{t+1} \mid s^{t}\right) \Phi_{i, t}^{E}\left(s^{t+1} \mid s^{t}\right)\left[1+R^{E}\left(s^{t+1} \mid s^{t}\right)\right] \\
-\frac{\Gamma_{t}^{\prime F}\left(\bar{\omega}_{i}^{F}\left(s^{t+1} \mid s^{t}\right)\right)}{\Phi_{i, t}^{\prime F}\left(\bar{\omega}_{i}^{F}\left(s^{t+1} \mid s^{t}\right)\right)}\left[1+R\left(s^{t}\right)\right] \\
+\frac{\left[1-\Gamma_{t}^{F}\left(\bar{\omega}_{i}^{F}\left(s^{t+1} \mid s^{t}\right)\right)\right] \Phi_{i, t}^{\prime E}\left(s^{t+1} \mid s^{t}\right)}{\Gamma_{t}^{\prime}\left(\bar{\omega}_{j_{i}}^{E}\left(s^{t+1} \mid s^{t}\right)\right)}\left[1-\Gamma_{t}^{E}\left(\bar{\omega}_{j_{i}}^{E}\left(s^{t+1} \mid s^{t}\right)\right)\right][1 \\
\left.+R^{E}\left(s^{t+1} \mid s^{t}\right)\right] \\
+\frac{\Gamma_{t}^{\prime F}\left(\bar{\omega}_{i}^{F}\left(s^{t+1} \mid s^{t}\right)\right) \Phi_{i, t}^{F}\left(s^{t+1} \mid s^{t}\right) \Phi_{i, t}^{\prime E}\left(s^{t+1} \mid s^{t}\right)}{\Phi_{i, t}^{\prime F}\left(\bar{\omega}_{i}^{F}\left(s^{t+1} \mid s^{t}\right)\right) \Gamma_{t}^{\prime E}\left(\bar{\omega}_{j_{i}}^{E}\left(s^{t+1} \mid s^{t}\right)\right)} \\
\left.+R^{E}\left(s^{t+1} \mid s^{t}\right)\right], \forall j_{i} .
\end{gathered}
$$




\section{References}

Adrian, T. and H. S. Shin, 2009, Money, Liquidity, and Monetary Policy. American Economic Review: Papers \& Proceedings, Vol. 99, pp. 600-605.

No. 3, pp. 418-437.

- 2011a, Financial Intermediary Balance Sheet Management, Annual Review of Financial Economics, Vol. 3, pp. 289-307.

- 2011b, Financial Intermediaries and Monetary Economics, In B. M. Friedman and M. Woodford (eds.), Handbook of Monetary Economics, Vol. 3, Amsterdam: NorthHolland, pp. 601-650.

Aghion, P., P. Bacchetta, and A. Banerjee, 2004, A Corporate Balance-Sheet Approach to Currency Crisis, Journal of Economic Theory, Vol. 119, pp. 6-30.

Ahmed, S., and A. Zlate, 2014, Capital Flows to Emerging Market Economies: A Brave New World? Journal of International Money and Finance, Vol. 48, pp. 221-248.

Ashcraft, A., J. McAndrews, and D. Skeie, 2011, Precautionary Reserves and the Interbank Market, Journal of Money, Credit and Banking, Vol. 43, pp. 311-348.

Bernanke, B.S., and M. Gertler, 1989, Agency Costs, Net Worth, and Business Fluctuations, American Economic Review, Vol. 79, pp. 14-31.

Bernanke, B.S., M. Gertler, and S. Gilchrist, 1999, The Financial Accelerator in a Quantitative Business Cycle Framework, In John B. Taylor and Michael Woodford (eds.), Handbook of Macroeconomics, 1C, Amsterdam: Elsevier Science, pp. 1341-93.

Borio, C., and P. Disyatat, 2011, Global Imbalances and the Financial Crisis: Link or No Link? Bank for International Settlements, BIS Working Papers, No. 346.

Borio, C., R. McCauley, and P. McGuire, 2011, Global Credit and Domestic Credit Booms, Bank for International Settlements BIS Quarterly Review, September 2011, pp. 43-57.

Broner, F., T. Didier, A. Erce, and S. L. Schmukler, 2013, Gross Capital Flows: Dynamics and Crises, Journal of Monetary Economics, Vol. 60, pp. 113-133.

Brunner, K., and A. H. Meltzer, 1963, The Place of Financial Intermediaries in the Transmission of Monetary Policy, American Economic Review, Vol. 53, pp. 372-82.

Brunnermeier, M., 2009, Deciphering the Liquidity and Credit Crunch 2007-2008, Journal of Economic Perspectives, Vol. 23, pp. 77-100.

Brunnermeier, M., A. Crocket, C. Goodhart, A. D. Persaud, and H. Shin, 2009, The Fundamental Principles of Financial Regulation, Geneva Reports on the World Economy, No. 11, Geneva: International Center for Monetary and Banking Studies and Centre for Economic Policy Research. 
Brunnermeier, M. K., and Y. Sannikov, 2015, International Credit Flows and Pecuniary Externalities, American Economic Journal: Macroeconomics, Vol. 7, pp. 297-338.

Bruno, V., and H. S. Shin, 2014, Assessing Macroprudential Policies: Case of South Korea. Scandinavian Journal of Economics, Vol. 116, pp. 128-157.

, 2015a, Cross Border Banking and Global Liquidity, Review of Economic Studies, Vol. 82, 535-564.

, 2015b, Capital Flows and the Risk-Taking Channel of Monetary Policy, Journal of Monetary Economics, Vol. 71, pp. 119-132.

Bruno, V., S. Kim, and H.S. Shin, 2018, Exchange Rates and the Working Capital Channel of Trade Fluctuations, Bank for International Settlements, BIS Working Papers, No. 694.

Caballero, J. A. 2014, Do Surges in International Capital Inflows Influence the Likelihood of Banking Crises? Economic Journal, 126, pp. 281-316.

Calström, C.T., and T.S. Fuerst, 1997, Agency Costs, Net Worth, and Business Fluctuations: A Comparable General Equilibrium Analysis, American Economic Review, Vol. 87, pp. 893-910.

Cecchetti, S.G., M.S. Mohanty, F. Zampolli, 2011, The Real Effects of Debt, Bank for International Settlements, BIS Working Papers, No. 352.

Cerutti, E., S. Claessens, and L. Ratnovski, 2017, Global Liquidity and Drivers of CrossBorder Bank Flows, Economic Policy, Vol. 32, pp. 81-125.

Céspedes, L.F., R. Chang, and A. Velasco, 2004, Balance Sheets and Exchange Rate Policy, American Economic Review, Vol. 94, pp. 1183-93.

Chang, R., and A. Fernández, 2010, On the Sources of Aggregate Fluctuations in Emerging Economies, NBER Working Paper, No. 15938.

Christiano, L., M. Eichenbaum, and C. L. Evans, 2005, Nominal Rigidities and the Dynamic Effects of a Shock to Monetary Policy, Journal of Political Economy, Vol. 113, pp. 1-45.

Christiano, L., R. Motto, and M. Rostagno, 2003, The Great Depression and the FriedmanSchwartz Hypothesis. Journal of Money, Credit, and Banking, 35, pp. 1119-1197.

No. 1192.

-, 2010, Financial Factors in Economic Fluctuations, ECB Working Paper Series, , 2014, Risk Shocks. American Economic Review, Vol. 104, pp. 27-65.

Chui, M., E. Kuruc, and P. Turner, 2016, A New Dimension to Currency Mismatches in the Emerging Markets: Non-Financial Companies, Bank for International Settlements, BIS Working Papers, No. 550. 
Claessens, S. and M. A. Kose, 2017, Macroeconomic Implications of Financial Imperfections: A Survey, Bank for International Settlements, BIS Working Papers, No. 677.

Committee on the Global Financial System, 2011, Global Liquidity Concept, Measurement and Policy Implications, CFGS Papers, No. 45.

Demirguc-Kunt, A., E. Feyen, and R. Levine, 2013, The Evolving Importance of Banks and Securities Markets, The World Bank Economic Review, Vol. 27, pp. 476-490.

Devereux, M.B., P.R. Lane and J. Xu, 2006, Exchange Rates and Monetary Policy in Emerging Market Economies, The Economic Journal, Vol. 116, pp. 478-506.

Elekdag, S., and I. Tchakarov, 2004, Balance Sheets, Exchange Rate Policy, and Welfare. Journal of Economic Dynamics and Control, Vol. 31, pp. 3986-4015.

Elekdag, S., A. Justiniano, and I. Tchakarov, 2006, An Estimated Small Open Economy Model of the Financial Accelerator, International Monetary Fund, IMF Staff Papers Vol. 53, pp. 219-241.

Forbes, K. J., and F. E. Warnock, 2012, Capital Flow Waves: Surges, Stops, Flight, and Retrenchment, Journal of International Economics, Vol. 88, pp. 235-251.

Fernandez-Corugedo, E., M. McMahon, S. Millard, and L. Rachel, 2011, Understanding the Macroeconomic Effects of Working Capital in the United Kingdom, Bank of England, Working Paper, No. 422.

Garcia-Cicco, J., R. Pancrazi, and M. Uribe, 2010, Real Business Cycles in Emerging Countries? American Economic Review, Vol. 100, pp. 2510-2531.

Gertler, M., S. Gilchrist, and F.M. Natalucci, 2007, External Constraints on Monetary Policy and the Financial Accelerator, Journal of Money, Credit, and Banking, Vol. 39, pp. 295-330.

Ghosh, A. R., M. S. Quereshi, J. I. Kim, and J. Zalduendo, 2014, Surges, Journal of International Economics, Vol. 92, pp. 266-285.

Ghosh, A. R., J. Ostry, and M. Quaershi, 2016, When Do Capital Inflow Surges End in Tears? American Economic Review: Papers and Proceedings, Vol. 106, pp. 581-585.

Gurley, J., and E. Shaw, 1955, Financial Aspects of Economic Development, American Economic Review, Vol. 45, pp. 515-538.

Hahm, J. H., H. S. Shin, and K. Shin, 2013, Noncore Bank Liabilities and Financial Vulnerability, Journal of Money, Credit and Banking, Vol. 45, pp. 3-36.

Hirakata, N., N. Sudo, and K. Ueda, 2009, Chained Credit Contracts and Financial Accelerator, IMES Discussion Paper Series, No. 2009-E-30.

, 2011, Do Banking Shocks Matter for the U.S. Economy? Journal of Economic Dynamics \& Control, Vol. 35, pp. 2042-2063. 
, 2013, Capital Injection, Monetary Policy, and Financial Accelerators, International Journal of Central Banking, Vol. 9, pp. 101-145.

, 2016, Chained Credit Contracts and Financial Accelerators, Economic Inquiry, Vol. 55, pp. 565-579.

Hofmann, B., I. Shim, and H. S. Shin, 2016, Sovereign Yields and the Risk-Taking Channel of Currency Appreciation, Bank for International Settlements, BIS Working Papers, No. 538.

Igan, D., and Z. Tan 2015, Capital Inflows, Credit Growth, and Financial Systems, International Monetary Fund, IMF Working Paper, WP/15/193.

International Monetary Fund, 2011a, Consolidated Spillover Report: Implications from the Analysis of the Systemic-5.

- 2011b, Cross-Cutting Themes in Advanced Economies with Emerging Market Banking Links, IMF Policy Paper, November 14, 2011.

, 2015a, Global Financial Stability Report, April 2015.

- 2015b, Global Financial Stability Report, October 2015.

Jeanne, O., and A. Korine, 2010, Excessive Volatility in Capital Flows: A Pigouvian Taxation Approach, American Economic Review Papers \& Proceedings, Vol. 100, 403-407.

Kim, C., 2014, Korea's Experiences with Macroproudential Policies, In Akerlof, G., O. Blanchard, D. Romer, and J. Stiglitz (eds.), What Have We Learned? Macroeconomic Policy After the Crisis, Cambridge: The MIT Press, pp. 99-128.

Kim, S.J., and H. S. Shin, 2012, Sustaining Production Chains Through Financial Linkages, American Economic Review, 102, pp. 402-406.

2013, Working Capital, Trade and Macro Fluctuations, mimeo.

Kiyotaki, N., and J. Moore, 1997, Credit Cycles, Journal of Political Economy, Vol. 105, pp. 211-248.

Korinek, A., 2011, The New Economics of Prudential Capital Controls: A Research Agenda, IMF Economic Review, Vol. 59, pp. 523-561.

Lane, P. R., and P. McQuade, 2014, Domestic Credit Growth and International Capital Flows, Scandinavian Journal of Economics, Vol. 116, pp. 218-252.

McCauley, R. N., P. McGuire, and V. Sushko, 2015, Global Dollar Credit, Economic Policy, Vol. 30, pp. 187-229.

McGuire, P., and G von Peter, 2012, The U.S. Dollar Shortage in Global Banking and the International Policy Response, International Finance, Vol. 15, pp. 155-178. 
Merrouche, O., and E. Nier, 2017, Capital Inflows, Monetary Policy, and Financial Imbalances, Journal of International Monetary and Finance, Vol. 77, pp. 117-142.

Mendoza, E. G., 1991, Real Business Cycles in a Small Open Economy, American Economic Review, Vol. 81, pp. 797-818.

Mendoza, E. G., and M. E. Terrones, 2008, An Anatomy of Credit Booms: Evidence from Macro Aggregates and Micro Data, NBER Working Paper, No. 14049.

Obstfeld, M., 2012a, Financial Flows, Financial Crises, and Global Imbalances, Journal of International Money and Finance, Vol. 31, pp. 469-480.

, 2012b, Does the Current Account Still Matter? American Economic Review: Papers \& Proceedings, Vol. 102, pp. 1-23.

, 2015, Trilemmas and Trade-Offs: Living with Financial Globalization. Bank for International Settlements, BIS Working Papers, No. 480.

Ólafsson, T. T. and T. G. Pétursson, 2011, Weathering the Financial Storm: Importance of Fundamentals and Flexibility. In Beblavý, M., D. Cobham, and L. Ódor (eds.) The Euro Area and the Financial Crisis, Cambridge: Cambridge University Press, pp. 23-58.

Rey, H., 2013, Dilemma not Trilemma: The Global Financial Cycle and Monetary Policy Independence, In Global Dimensions of Unconventional Monetary Policy, proceedings of the Federal Reserve Bank of Kansas City Jackson Hole Symposium 2013, pp. 285-333.

Schmitt-Grohé, S., and M. Uribe, 2003, Closing Small Open Economy Models, Journal of International Economics, Vol. 61, pp. 163-185.

Shin, H. S., 2012, Global Banking Glut and Loan Risk Premium, IMF Economic Review, Vol. 60, pp. 155-192.

2013, The Second Phase of Global Liquidity and Its Impact on Emerging Economies, Keynote address at the Federal Reserve Bank of San Francisco Asia Economic Policy Conference, November 3-5, 2013.

Tarashev, N., S. Avdjiev, and B. Cohen, 2016, International Capital Flows and Financial Vulnerabilities in Emerging Market Economies: Analysis and Data Gaps, Note submitted to the G20 International Financial Architecture Working Group.

Tobin, J., and W.C. Brainard, 1963, Financial Intermediaries and the Effectiveness of Monetary Control, American Economic Review, Vol. 52, pp. 383-400.

Townsend, R.B., 1979, Optimal Contracts and Competitive Markets with Costly State Verification, Journal of Economic Theory, Vol. 21, pp. 265-293.

Turner, P., 2014, The Global Long-Term Interest Rate, Financial Risks and Policy Choices in EMEs, Bank for International Settlements, BIS Working Papers, No. 441. 
Ueda, K., 2012, Banking Globalization and International Business Cycles, Journal of International Economics, Vol. 86, pp. 1-16.

Uribe, M., and V.Z. Yue, 2006, Country Spreads and Emerging Countries: Who Drives Whom? Journal of International Economics, Vol. 69, pp. 6-36. 